\title{
Estimation of Chloramine Decay in Drinking Water Distribution Systems
}

by

\author{
Emily Ann Curling
}

A thesis submitted in conformity with the requirements

for the degree of Master of Applied Science

Graduate of Department Civil and Mineral Engineering

University of Toronto

(C) Copyright by Emily Ann Curling 2021 


\title{
Estimation of Chloramine Decay in Drinking Water Distribution Systems
}

\author{
Emily Ann Curling \\ Master of Applied Science \\ Graduate Department of Civil and Mineral Engineering \\ University of Toronto
}

2021

\begin{abstract}
Development of a means to identify and predict factors associated with chloramine decay in drinking water distribution systems could assist in providing targeted operational strategies which ensure regulatory compliance and ultimately lead to major cost-savings. In this study, novel benchscale pipe section reactors (PSRs) were utilized to evaluate the impact of source water (surface or groundwater), pipe material, pipe age, and flow velocity on chloramine decay in a distribution system in the Greater Toronto Area, Ontario, Canada. Batch tests in amber glass bottles quantified decay in treated water which were compared to low- and high-flow PSR experiments to elucidate the impact of water velocity and pipe material on monochloramine decay. Of the factors examined, pipe material and condition (e.g., old or new) were identified as the most critical. Overall, the results of this study reinforce the importance of determining the source of residual disinfectant decay when considering chloramination.
\end{abstract}




\section{ACKNOWLEDGMENTS}

This project was funded by the Natural Sciences and Engineering Research Council of Canada (NSERC) Chair in Drinking Water Research at the University of Toronto as well as the Regional Municipality of York, Ontario. York Region was consulted in designing, planning, and coordinating this study and has authorized the publication of this work.

Thank you kindly to my supervisor, Dr. Robert Andrews, as well as to Dr. Susan Andrews and Dr. Michael McKie; your counsel guided me throughout my degree, and I am incredibly grateful for your leadership.

A special thank you to Laura Meteer, Blair Saunders, Alan McClenaghan, Jim Wang, and Jason Moore for your insight and collaboration on this work.

Kind thanks to the members and alumni of the Drinking Water Research Group for your kindness and counsel: Dr. Ron Hofmann, Liz Taylor-Edmonds, Jennifer Lee, Nicole Zollbrecht, Abdallatif Abdalrhman, Husein Almuhtaram, Carlos Alonzo Moya, Laura Alvarez, Itai Arbiv, Jamal Azzeh, Jia Bian, Emily Bridgehouse, Domenica Cevallos Nunez, Tianyi Chen, Ashlyn Cherian, Sam Cherniak, Grace Crowe, Chengyang Jiang, Meaghan Keon, Arif Khan, Ian Lake-Thompson, Livia Li, Tyler Malkoske, Nathan Moore, Yucong Shi, Arundhati Tewari, Florence Udenby, Chengjin Wang, Chuqiao Yuan, and Jie Yuan.

Finally, thank you to my family and friends for your continuous love and support. 


\section{TABLE OF CONTENTS}

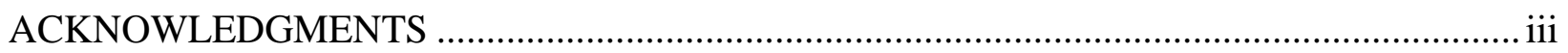

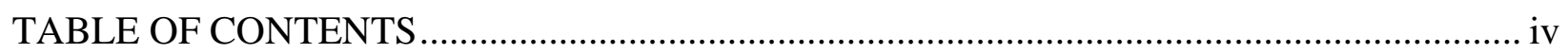

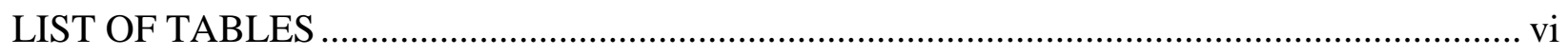

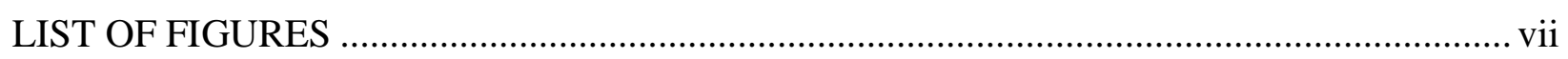

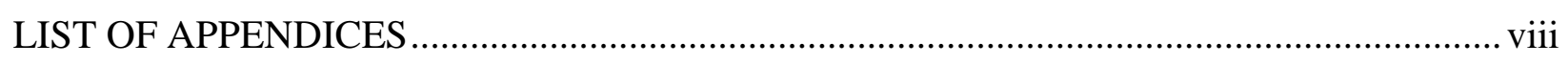

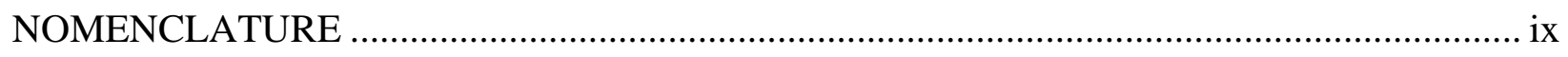

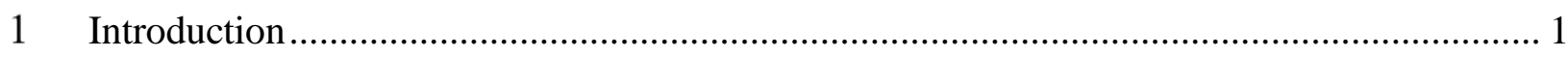

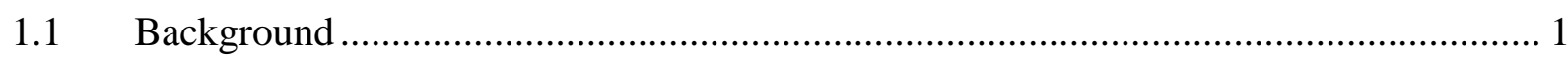

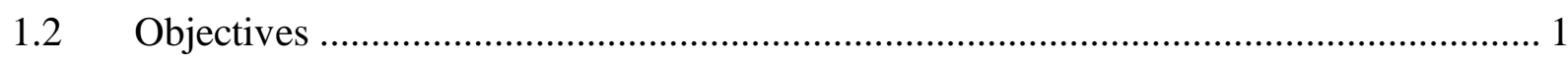

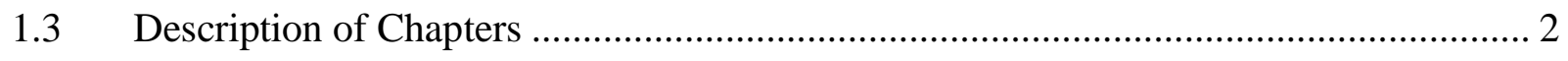

1.4 Associated Journal Publications …………………............................................. 2

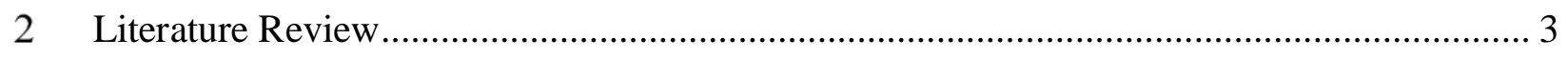

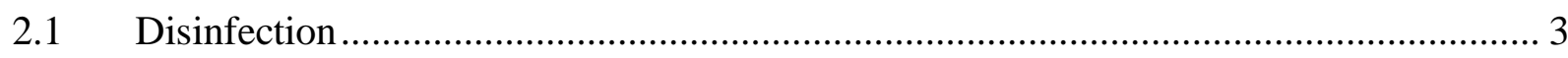

2.2 Factors Impacting Chloramine Decay ...................................................................... 4

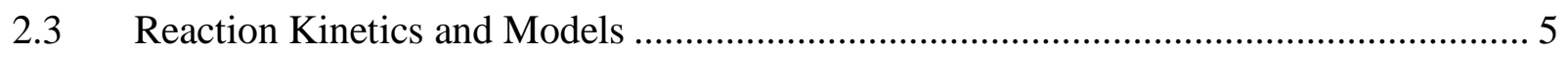

2.4 Estimation of Chloramine Decay in Distribution Systems .......................................... 5

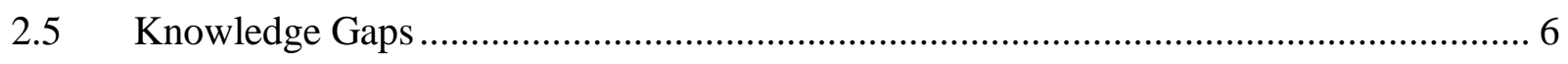

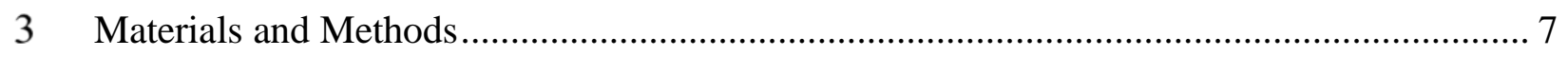

3.1 Pipe Section Reactor Design and Construction …………………............................. 7

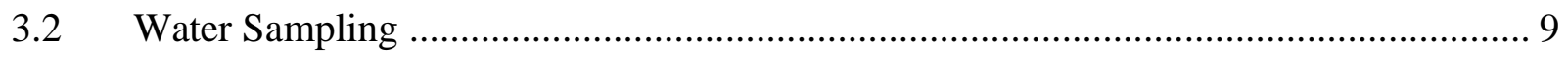

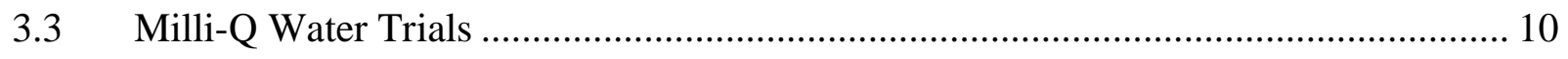

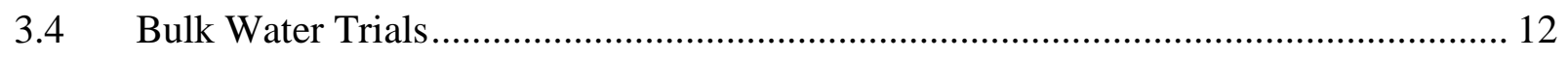

3.5 Pipe Section Reactor Trials.............................................................................. 12 
3.6 Calculation of Surface Reaction Rates ............................................................... 12

3.6.1 Calculation of $\mathrm{k}_{\mathrm{w}}$ for Cast-Iron Pipe (Mass Transfer Dependent on Internal

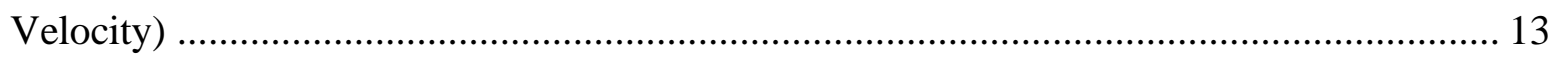

3.6.2 Calculation of $\mathrm{k}_{\mathrm{w}}$ for PVC Pipe (Mass Transfer Independent of Internal Velocity)

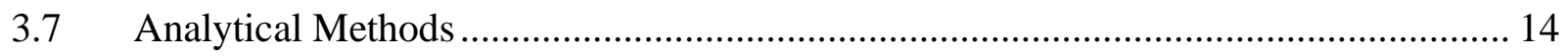

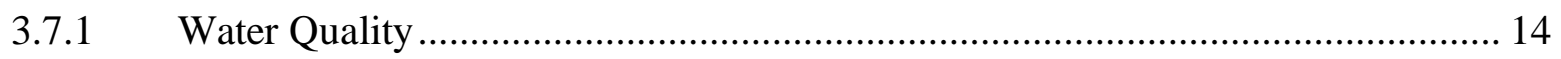

3.7.2 Dissolved Organic Carbon (DOC) ................................................................ 15

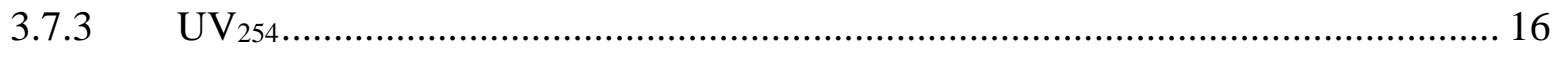

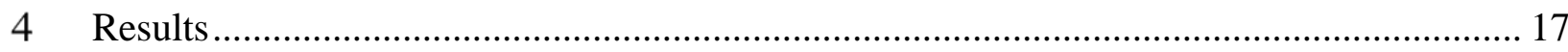

4.1 Batch Trials: Impact of Bulk Water Source on Chloramine Decay .............................. 17

4.1.1 Distribution System Water Quality ..................................................................... 17

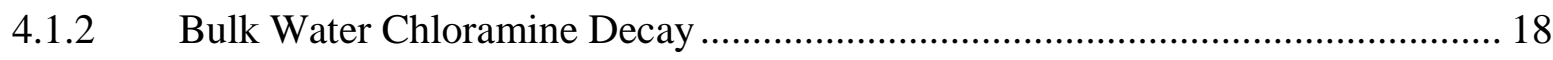

4.2 Impact of Pipe Material and Flow Regime ……….................................................. 21

4.2.1 Decay Associated with Distribution System Pipe Material ................................... 21

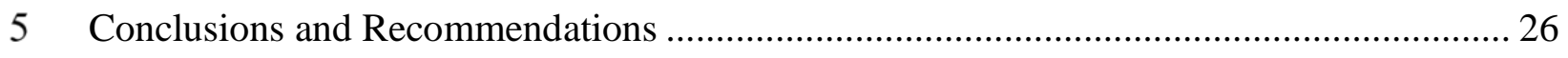

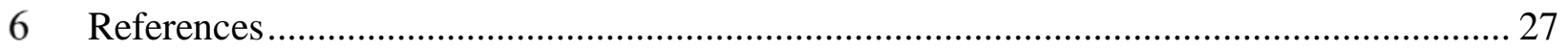

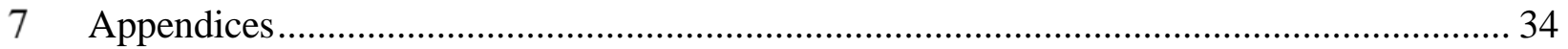




\section{LIST OF TABLES}

Table 3-1: Comparison of Zero- and First-Order Total Chlorine Decay Constants for Milli-Q stored in Chloramine Demand-Free (DF) Amber Glass Bottles $\left(12{ }^{\circ} \mathrm{C} \pm 2{ }^{\circ} \mathrm{C}\right)$, in Acrylic PSR1

$\left(12{ }^{\circ} \mathrm{C} \pm 2{ }^{\circ} \mathrm{C}\right)$, and in Acrylic PSRs $1-3\left(20^{\circ} \mathrm{C} \pm 3{ }^{\circ} \mathrm{C}\right)$ 10

Table 4-1: Water quality parameters for initial batch water trials. 17

Table 4-2: Average Water Quality Values for Groundwater and Surface Water in PSR Trials... 18 Table 4-3: Comparing Zero, First and Second-Order Total Chlorine Bulk Water Decay Constants from the Present Study to those from the Literature 20

Table 4-4: Comparison of reduction in chlorine concentration - present study and published literature 24

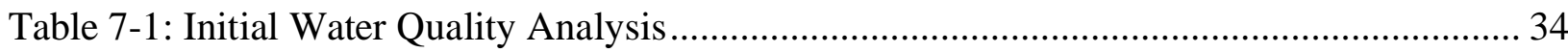

Table 7-2: Preparation of Stock Solutions and Monochloramine ........................................... 35

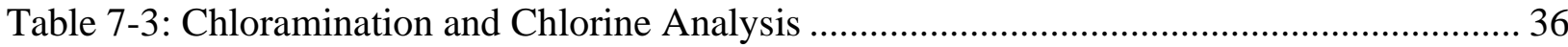

Table 7-4: Preparation of Chloramine Demand Free Bottles ............................................. 36

Table 7-5: Reducing Chloramine Demand in the Pipe Section Reactors Prior to Experiments ... 36

Table 7-6: Setting up Pipe Section Reactor Experiments ................................................... 37

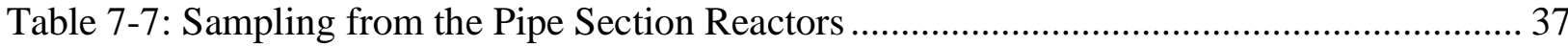

Table 7-8: Tracer Dye Velocity Calibration Method .............................................................. 38

Table 7-9: Inkbird Temperature Controller Calibration Method ............................................. 38

Table 7-10: Pressure Transmitter Calibration Method …....................................................... 39

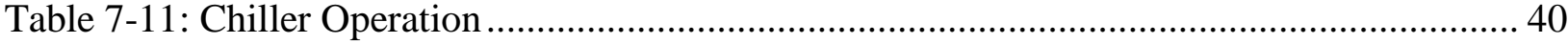

Table 7-12: Hazen-Williams coefficients for various pipe materials 


\section{LIST OF FIGURES}

Figure 3-1: Pipe Section Reactor Schematic 7

Figure 3-2: Pipe Section Reactor with Acrylic Outer Cylinder to Allow Visualization of Internal Components 8

Figure 3-3: Pipe Section Reactor Calibration Curve for approximate water speed (m/s) vs. motor power (\%) for Pipe Section Reactors 1-3.

Figure 3-4 A and B: Total Chlorine Decay over 72 hours for Milli-Q (MQ) Water stored in Chloramine Demand-Free (DF) Amber Glass Bottles $\left(12{ }^{\circ} \mathrm{C} \pm 1{ }^{\circ} \mathrm{C}\right)$, in Acrylic PSR1 $\left(12{ }^{\circ} \mathrm{C} \pm 1\right.$ ${ }^{\circ} \mathrm{C}$ ), and in Acrylic PSRs 1-3 (20 $\left.{ }^{\circ} \mathrm{C} \pm 3{ }^{\circ} \mathrm{C}\right)$, Fit to Zero- (3-4 A) and First-Order (3-4 B) Model.

Figure 3-5: DOC Calibration Curve (January 2020) 15

Figure 4-1A-C: Batch Monochloramine Decay at $12{ }^{\circ} \mathrm{C} \pm 2{ }^{\circ} \mathrm{C}$ (as Total Chlorine) Fit to Zero (4-1A), First (4-1B), and Second Order (4-1C) Models.

Figure 4-2A and B: Monochloramine Decay (Total Chlorine) for Groundwater Batch and PSR Experiments, Fit to Zero-Order Model (4-2A) and First-Order Model (4-2B) - Maintained at 12 ${ }^{\circ} \mathrm{C} \pm 2{ }^{\circ} \mathrm{C}$. 21

Figure 4-3A and B: Comparison of Observed First-Order Reaction Rate Constants (kobs, 4-3A) and Surface Reaction Rate Constants $\left(\mathrm{k}_{\mathrm{w}} 4-3 \mathrm{~B}\right)$ for Ground and Surface Waters $\left(12{ }^{\circ} \mathrm{C} \pm 2{ }^{\circ} \mathrm{C}\right) .23$ Figure 7-1: Estimated Flow Velocity vs. Motor Power for Ductile Iron, PVC, New Cast-Iron, and Old Cast-Iron Based on Hazen-Williams Roughness Coefficients. 


\section{LIST OF APPENDICES}

Appendix A: Standard Operating Procedures ...................................................................... 34

Appendix B: Estimating Water Velocity in PVC and Cast-Iron Pipe Segments....................... 41 


\section{NOMENCLATURE}

\begin{tabular}{|c|c|}
\hline$\%$ & Percent \\
\hline${ }^{\circ} \mathrm{C}$ & Degrees Celsius \\
\hline${ }^{\circ} \mathrm{F}$ & Degrees Fahrenheit \\
\hline$\Delta \mathrm{P}$ & Change in pressure $(\mathrm{Pa})$ \\
\hline$\rho$ & Density $\left(\mathrm{kg} / \mathrm{m}^{3}\right)$ \\
\hline$\mu$ & Dynamic viscosity $\left(\mathrm{Pa}^{*} \mathrm{~s}\right)$ \\
\hline \pm & Plus/ minus \\
\hline$\leq$ & Less than or equal to \\
\hline$\mu \mathrm{L}$ & Microliter \\
\hline$\mu \mathrm{M}$ & Micromolar \\
\hline APHA & American Public Health Association \\
\hline AWWA & American Water Works Association \\
\hline $\mathrm{C}$ & Carbon, concentration or molarity ( $\mathrm{M}$ or $\mathrm{mg} / \mathrm{L})$ \\
\hline $\mathrm{C}_{5} \mathrm{H}_{7} \mathrm{O}_{2} \mathrm{~N}$ & Natural organic matter \\
\hline $\mathrm{CA}$ & Calibrate \\
\hline $\mathrm{Cd}$ & Low-temperature differential \\
\hline $\mathrm{CI}$ & Cast-iron \\
\hline $\mathrm{Cl} / \mathrm{Cl}_{2}$ & Chlorine \\
\hline $\mathrm{Cl}: \mathrm{N}$ & Chlorine: nitrogen ratio \\
\hline $\mathrm{Cl}_{2 \text { (final) }}$ & Final chlorine concentration $(\mathrm{mg} / \mathrm{L})$ \\
\hline $\mathrm{Cl}_{2 \text { (initial) }}$ & Initial chlorine concentration $(\mathrm{mg} / \mathrm{L})$ \\
\hline $\mathrm{CO}_{2}$ & Carbon dioxide \\
\hline $\mathrm{D}$ & Molecular diffusivity $\left(\mathrm{m}^{2} / \mathrm{h}\right)$ \\
\hline $\mathrm{d}$ & Day(s) or hydraulic diameter (m) \\
\hline $\mathrm{DBP}$ & Disinfection by-product \\
\hline $\mathrm{dC} / \mathrm{dt}$ & Change in concentration over time $\left(\mathrm{M} / \mathrm{h}\right.$ or $\left.\mathrm{mg} \mathrm{L}^{-1} \mathrm{~h}^{-1}\right)$ \\
\hline $\mathrm{DF}$ & Demand-free \\
\hline DI & Deionized \\
\hline DO & Dissolved oxygen \\
\hline DOC & Dissolved organic carbon \\
\hline
\end{tabular}




\begin{tabular}{|c|c|}
\hline $\mathrm{e}$ & Pipe roughness (m) \\
\hline $\mathrm{f}$ & Fanning friction factor \\
\hline $\mathrm{Fe}$ & Iron \\
\hline $\mathrm{ft}$ & Foot \\
\hline $\mathrm{g}$ & $\operatorname{Gram}(\mathrm{s})$ \\
\hline $\mathrm{g} / \mathrm{L}$ & Grams per liter \\
\hline $\mathrm{h}$ & Hour(s) \\
\hline $\mathrm{H}$ & Hydrogen \\
\hline $\mathrm{H}^{+}$ & Hydrogen ion \\
\hline $\mathrm{HCO}_{3}{ }^{-}$ & Bicarbonate \\
\hline $\mathrm{Hd}$ & High-temperature differential \\
\hline $\mathrm{H}_{2} \mathrm{O}$ & Water \\
\hline HP & Horsepower \\
\hline in. & Inch \\
\hline $\mathrm{k}$ & Empirical constant \\
\hline $\mathrm{kb}$ & First-order bulk water decay rate $\left(\mathrm{h}^{-1}\right)$ \\
\hline $\mathrm{k}_{\mathrm{f}}$ & Mass transfer coefficient $(\mathrm{m} / \mathrm{h})$ \\
\hline $\mathrm{kg}$ & Kilogram \\
\hline KHP & Potassium hydrogen phthalate \\
\hline Kobs & First-order observed decay rate $\left(\mathrm{h}^{-1}\right)$ \\
\hline $\mathrm{k}_{\mathrm{w}}$ & Surface reaction rate $(\mathrm{m} / \mathrm{h})$ \\
\hline $\mathrm{L}$ & Litre(s) or length (m) \\
\hline $\mathrm{M}$ & Molar \\
\hline $\mathrm{m}$ & Metre(s) \\
\hline $\mathrm{mA}$ & Milliamps \\
\hline $\mathrm{mg} / \mathrm{L}$ & Milligram/ liter \\
\hline $\mathrm{mL}$ & Milliliter(s) \\
\hline MQ & Milli-Q ® \\
\hline $\mathrm{mV}$ & Millivolts \\
\hline $\mathrm{n}$ & Sample size \\
\hline $\mathrm{N}$ & Nitrogen \\
\hline $\mathrm{NH}_{3}$ & Ammonia \\
\hline
\end{tabular}




$\begin{array}{ll}\mathrm{NH}_{4}{ }^{+} & \text {Ammonium } \\ \mathrm{NH}_{2} \mathrm{Cl} & \text { Monochloramine } \\ \mathrm{NO}_{2} & \text { Nitrogen dioxide } \\ \mathrm{NOM} & \text { Natural organic matter } \\ \mathrm{NR} & \text { Not reported } \\ \mathrm{O} & \text { Oxygen } \\ \mathrm{ORP} & \text { Oxidation-reduction potential (mV) } \\ \mathrm{Pa} & \text { Pascals } \\ \mathrm{pH} & \text {-log (hydrogen ion concentration) } \\ \mathrm{PSR}(\mathrm{s}) & \text { Pipe Section Reactor(s) } \\ \mathrm{PVC} & \text { Polyvinyl chloride } \\ \mathrm{Q} & \text { Volumetric flow rate (m } 3 / \mathrm{s}) \\ \mathrm{Re} & \text { Reynolds number } \\ \mathrm{rh} \text { or R } & \text { Hydraulic radius (m) } \\ \mathrm{S} & \text { Slope } \\ \mathrm{s} & \text { Second } \\ \mathrm{Sc} & \text { Schmidt number } \\ \mathrm{SUVA} & \text { Specific UV absorbance } \\ \mathrm{TOC} & \text { Total organic carbon } \\ \text { tS } & \text { Temperature setpoint } \\ \mathrm{UHP} & \text { Ultra-high purity } \\ \mathrm{USA} & \text { United States of America } \\ \mathrm{USEPA} & \text { United States Environmental Protection Agency } \\ \mathrm{UV} & \text { Ultraviolet } \\ \mathrm{UV} & \text { Ultraviolet light absorbance at 254 nm } \\ \mathrm{UV} / \mathrm{Vis} & \text { Ultraviolet and visible light } \\ \mathrm{V} & \text { Velocity (m/s) } \\ \mathrm{v} / \mathrm{v} & \text { Volume/ volume } \\ & \end{array}$




\section{Chapter 1: Introduction}

\section{Introduction}

\subsection{Background}

The use of chloramines as a secondary disinfectant is becoming more common due to its ability to reduce disinfection by-product (DBP) formation and improve residual stability when compared to free chlorine; however, sustaining an appropriate chloramine residual in distribution systems can sometimes be challenging, whereby water utilities allocate significant funds and resources to system maintenance (Xue et al., 2014). Although several factors have been identified as influential in chloramine decay, including pipe material, flow regime, and biofilm on the pipe walls, the cause of the residual decay is currently unknown. Without the identification of a specific mechanism responsible for residual decay, effective mitigation strategies cannot be proposed.

To evaluate the factors which impact chloramine residual decay, including changing treated water conditions, hydraulic fluctuations, pipe aging, and biofilm or scale development, bench-scale Pipe Section Reactors (PSRs) were constructed using pipe sections harvested from a distribution system in Ontario, Canada. Using the Pipe Section Reactors, the influence of pipe-wall reactions on monochloramine decay as total chlorine decay was assessed for finished groundwater and surface water collected from the distribution system in Ontario, Canada.

Overall, this thesis has been developed as part of a plan to understand better the causes of chloramine residual decay in drinking water distribution systems, such that mitigation and maintenance strategies may subsequently be proposed to effectively reduce the cost currently associated with maintaining residuals throughout the system.

\subsection{Objectives}

- Elucidate key factors which influence chloramine demand and composition in drinking waters.

- Characterize the rate of chloramine residual decay in relation to pipe material and operating conditions. 


\subsection{Description of Chapters}

Chapter 2: background regarding primary and secondary disinfection in water treatment and existing knowledge gaps regarding the decay of chloramine in drinking water distribution systems.

Chapter 3: an overview of methods in this study, including Pipe Section Reactor design and construction, water sampling, batch and PSR trials, calculation of surface reaction rates, and analytical methods.

Chapter 4: presentation of results and discussion from batch bulk water decay tests and Pipe Section Reactor experiments.

Chapter 5: summary of identified factors contributing to chloramine decay and recommendations to mitigate chloramine decay in distribution systems.

\subsection{Associated Journal Publications}

- Portions of this thesis have been submitted to Journal Water Process Engineering as "Curling, E.C., McKie, M.J., Meteer, L., Saunders, B., Andrews, S.A., Andrews., R.C. Estimation of Chloramine Decay in Drinking Water Distribution Systems". 


\section{Chapter 2: Literature Review}

\section{Literature Review}

\subsection{Disinfection}

The inactivation or removal of pathogenic microorganisms through disinfection is a key outcome

of drinking water treatment, commonly achieved with UV technologies or through chemical disinfection with free chlorine or chloramine. Primary disinfection in drinking water treatment disinfects water to the level required by the local legislature as part of the treatment train at the drinking water treatment plant itself. In contrast, secondary disinfection maintains a disinfectant residual that mitigates microbial growth and biofilm formation in distribution systems and provides a measurable indication that water quality has been maintained from the plant to the point of use.

With regards to secondary disinfection, free chlorine or chloramine are typically employed as disinfectants, and the behavior and decay rates of the disinfectant residual in the distribution system depend on the disinfectant in question. Secondary disinfection with free chlorine, or chlorination, is achieved by the addition of chlorine gas or liquid sodium hypochlorite. Chloramination, on the other hand, requires treating water with a combination of free chlorine and ammonia.

The use of chloramines as a secondary disinfectant has become more common due to their ability to reduce disinfection by-product (DBP) formation and improve residual stability compared to free chlorine (Moradi et al., 2017; Westbrook and DiGiano, 2009). However, sustaining an appropriate chloramine residual in distribution systems may be challenging, whereby water utilities may direct significant funds and resources to system maintenance (Xue et al., 2014). In addition, utilities must manage residual chloramine concentrations to help ensure regulatory compliance, minimize taste and odor, pipe corrosion, and DBP formation (Seidel et al., 2018). As such, elucidating key factors that influence chloramine demand may enable municipalities to develop strategies to reduce decay in distribution systems. 


\subsection{Factors Impacting Chloramine Decay}

Generally speaking, distribution system-related chlorine or chloramine decay rates may be divided into that associated with pipe-wall reactions and decay associated with bulk water chemistry (Ozdemir and Buyruk, 2018). Decay related to pipe material is considered to be higher than that attributed to water due to reactions with metallic species (Vikesland and Valentine, 2000; Bal Krishna et al., 2018), aluminosilicates in cement-lined ductile iron pipe (Westbrook and DiGiano, 2009), organics leached from polymer pipe (Kiéné et al., 1998), as well as biofilm or natural organic matter (NOM) that may be attached to the pipe wall (Wang et al., 2013; Xue et al., 2014; Huang et al., 2016; Zheng et al., 2016). Pipe wall reactions consist mainly of complex redox reactions with biomass and metals, especially iron, commonly with biomass formation and scaling both increasing with pipe age. Along pipe walls, chloramine reactions with iron may be approximated according to the following reaction (Woolschlager et al., 2001; Pirou et al., 1997):

$$
1 / 2 \mathrm{NH}_{2} \mathrm{Cl}+\mathrm{H}^{+}+\mathrm{Fe}^{2+} \rightarrow \mathrm{Fe}^{3+}+1 / 2 \mathrm{NH}_{4}^{+}+1 / 2 \mathrm{Cl}^{-} \quad \text { Reaction } 1
$$

In addition, organic constituents accumulated along pipe walls may be oxidized, including natural organic matter (NOM), as represented in Reaction 2 (Woolschlager et al., 2001; Hoover et al., 1951).

$$
\begin{gathered}
1 / 10 \mathrm{C}_{5} \mathrm{H}_{7} \mathrm{O}_{2} \mathrm{~N}(\mathrm{NOM})+\mathrm{NH}_{2} \mathrm{Cl}+9 / 10 \mathrm{H}_{2} \mathrm{O} \rightarrow 4 / 10 \mathrm{CO}_{2}+ \\
1 / 10 \mathrm{HCO}_{3}+11 / 10 \mathrm{NH}_{4}{ }^{+}+\mathrm{Cl}^{-}
\end{gathered}
$$

Reaction 2

NOM and biomass on pipe walls may also contribute to nitrification, again consuming chloramine (Huang et al., 2016; Cunliffe, 1991).

When considering bulk water, nitrification (Reaction 3; Bal Krishna et al., 2018; Cunliffe, 1991; Woolschlager et al., 2001) and acid-catalyzed auto-decomposition (Reaction 4) (Jafvert and Valentine, 1992; Jafvert and Valentine, 1985; Vikesland et al., 1996; Woolschlager et al., 2001) also serve as primary contributors to decay.

$$
\begin{array}{lr}
\mathrm{NH}_{2} \mathrm{Cl}+\mathrm{NO}_{2}+\mathrm{H}_{2} \mathrm{O} \rightarrow \mathrm{NH}_{3}+\mathrm{HCl} & \text { Reaction } 3 \\
3 \mathrm{NH}_{2} \mathrm{Cl} \rightarrow \mathrm{N}_{2}+\mathrm{NH}_{3}+3 \mathrm{Cl}^{-}+3 \mathrm{H}^{+} & \text {Reaction } 4
\end{array}
$$

Finally, decay also depends on water characteristics including temperature (Monteiro et al., 2017; Powell et al., 2000; Hua et al., 1999), flowrate, velocity, varying vs. constant hydraulic conditions 
(Aisopou et al., 2014; Zhao et al., 2019; Menaia et al., 2003), and pH (Vikesland and Valentine, 2000). In particular, as monochloramine auto-decomposition is acid-catalyzed, it is sensitive to changes in $\mathrm{pH}$ (Jafvert and Valentine, 1985). However, the degree to which each factor contributes to chloramine decay is system-specific and has not been well documented in the literature.

\subsection{Reaction Kinetics and Models}

Based on the key factors described, models for chloramine decay have been developed (Ozdemir and Buyruk, 2018; Fisher et al., 2017), several of which include first- and second-order decay kinetics (Valentine et al., 1998; Shang et al., 2008). Use of a first-order model may be effective and practical if based on system-specific characteristics including temperature, $\mathrm{pH}$, TOC, pipe material, and pipe age (Powell et al., 2000; Ozdemir and Buyruk, 2018). As such, application of a first-order model was preferred for this study; however, data-fit zero- and second-order models were also considered.

\subsection{Estimation of Chloramine Decay in Distribution Systems}

Required data may be collected in the field or at pilot/ bench-scale. Typically, field-based methods rely on the measurement of decay between two points in a distribution system (Hallam et al., 2002) and are considered to represent both pipe wall and bulk water impacts. Wall-related decay can be calculated retroactively by subtracting bulk water decay as determined in the lab from total decay. Computational models may also be employed (Vasconcelos et al., 1997; Rossman et al., 1994). For example, the USEPA developed a model that includes decay rates for water and pipe wall (Shang et al., 2008; Rossman, 2000); however, it has not been sufficiently shown to consider the effect of biofilm (Fisher et al., 2017).

Pilot-scale methods typically incorporate pipe loops, pipe segments harvested from the field, as well as the collection of water, and thereby serve as a common alternative to field testing (Mutoti et al., 2007; Jamwal and Kumar, 2016; Douterelo et al., 2016; Clark and Haught, 2005). Benchscale evaluations are often a practical alternative or supplement to pilot-scale trials. They are costeffective and compact, allow water quality to be more easily controlled, and allow the user to vary pipe material, age, and quality. Typical bench-scale methods include the use of annular reactors as well as pipe section reactors (PSRs). In a PSR, a pipe section $(0.6 \mathrm{~m}, 2 \mathrm{ft})$ harvested from the distribution system is fitted with an inner cylinder and impeller to drive flow along the pipe wall 
(Westbrook and DiGiano, 2009; DiGiano and Zhang, 2005). In contrast, an annular reactor uses small coupons of pipe, thereby limiting surface area (Baribeau et al., 2001). Both PSRs and pilotscale pipe loops have been identified as appropriate approaches to estimate chloramine residuals and decay in distribution systems.

In this study, factors associated with chloramine decay were elucidated using PSRs and included an examination of pipe material (cast-iron or PVC - new or harvested) along with water type: treated groundwater, treated surface water, and a mixture of both.

\subsection{Knowledge Gaps}

In this study, the impact of factors associated with chloramine decay in distribution systems is elucidated through the use of batch tests (Pipe Section Reactors) by examining pipe material (castiron or PVC - new or harvested) and water type: treated groundwater, treated surface water, and a mixture of both.

In addition to identifying key factors contributing to chloramine decay in distribution systems, appropriate strategies to mitigate chloramine decay are proposed with the goals of reducing costs associated with system maintenance to maintain an appropriate residual. 


\section{Chapter 3: Materials and Methods}

\section{Materials and Methods}

\subsection{Pipe Section Reactor Design and Construction}

Pipe section reactors (PSRs) developed for this study were based on a design reported by DiGiano and Zhang (2005) and Westbrook and DiGiano (2009) to simulate the flow regime in a distribution system. A section of pipe $(0.61 \mathrm{~m}$ long for virgin PVC and harvested cast iron and $0.51 \mathrm{~m}$ long for harvested PVC pipe) was sealed with Teflon O-rings held between two end plates using stainless steel support rods and nuts. An impeller shaft and a $10.2 \mathrm{~cm} \mathrm{(4")} \mathrm{diameter} \mathrm{inner} \mathrm{acrylic} \mathrm{cylinder}$ were fit concentrically within the reactor (Figure 3-1). The shaft was connected to a 1/7-1/4 HP motor (Dayton \#4Z143); a motor controller (Cytron MD30C) was used to vary water velocity within the reactor. The annular space between the inner cylinder and the pipe constricted the flow of recirculating water to simulate distribution system water velocities along the pipe wall. Other components of each PSR included influent and effluent sampling ports, pressure transducers, temperature transducers and a stainless-steel heat exchanger to regulate temperature, along with a perforated stainless steel baffling plate to reduce water vortexing.

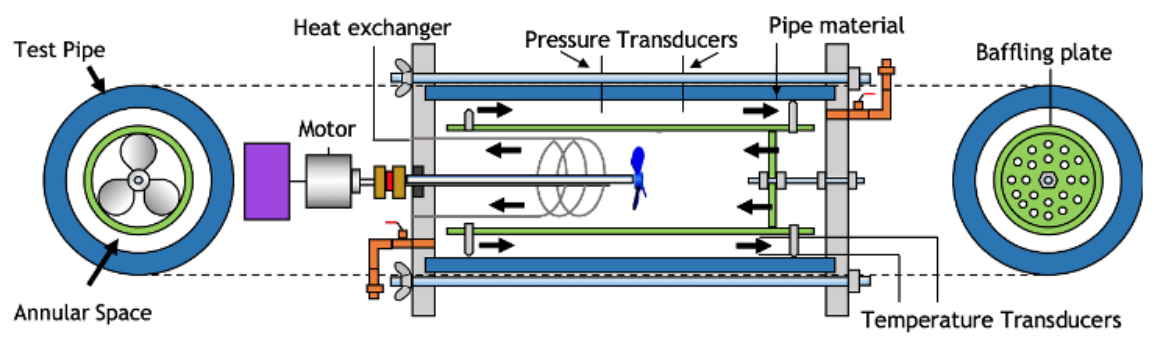

Figure 3-1: Pipe Section Reactor Schematic

To evaluate the effect of pipe material and pipe age, PSRs were used to assess using harvested and new cast iron (CI), as well as harvested and new polyvinyl chloride (PVC) pipe. Initially, a PSR constructed using acrylic allowed visualization of the internal components and the assessment of the baseline monochloramine decay associated with individual components (Figure 3-2). 

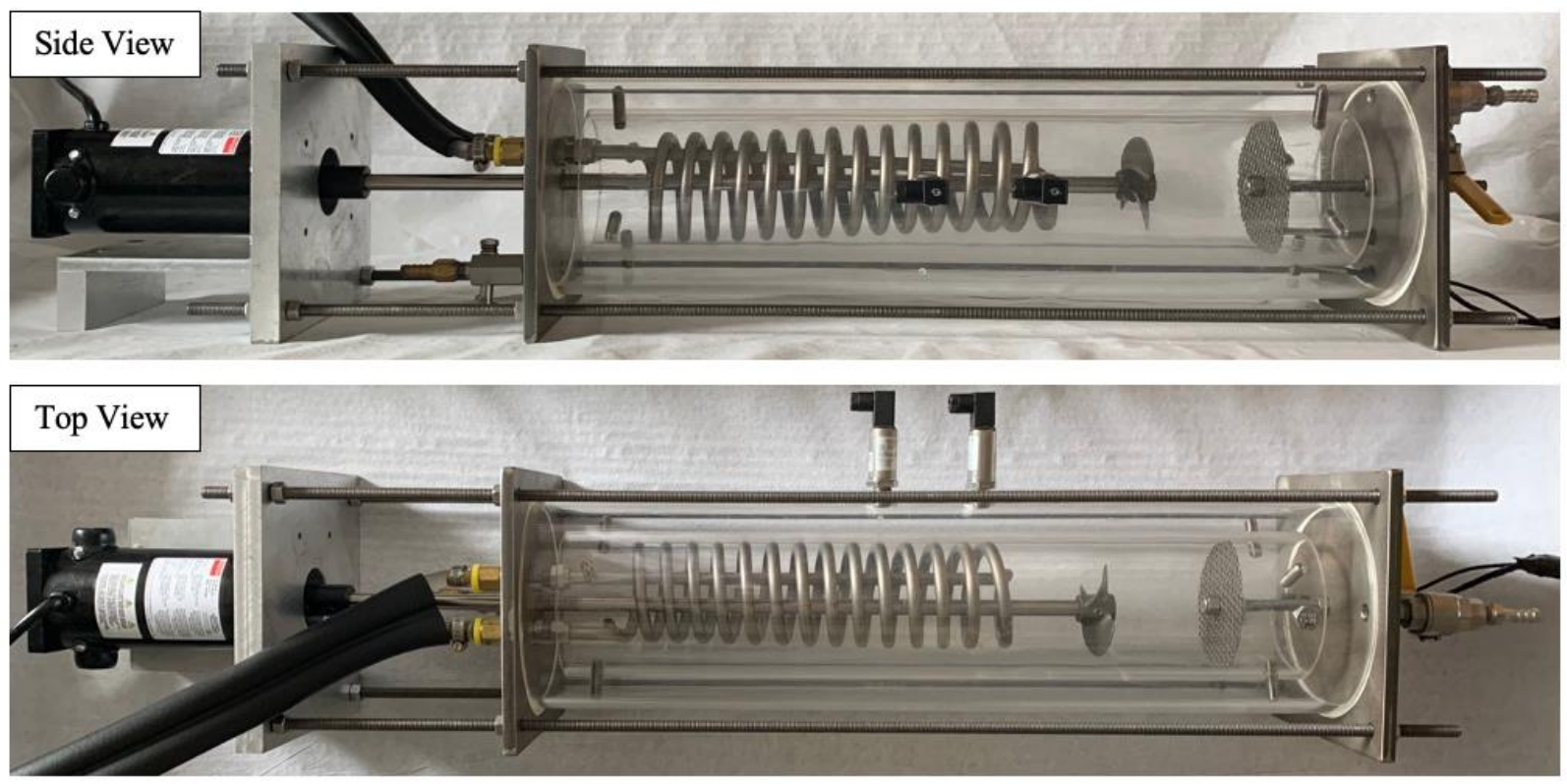

Figure 3-2: Pipe Section Reactor with Acrylic Outer Cylinder to Allow Visualization of Internal Components

A "new" CI segment was prepared by milling the inside of a harvested pipe segment. Temperature within each PSR was maintained at $12{ }^{\circ} \mathrm{C} \pm 2{ }^{\circ} \mathrm{C}$ to represent the average temperature in the distribution system, by incorporating an external temperature controller (Inkbird ITC-308) and by recirculating a 50/50 vol/vol mixture of glycol/ distilled water through the stainless-steel heat exchanger within the reactor. The glycol/ distilled water mixture was cooled to $4{ }^{\circ} \mathrm{C}$ using a $1 / 2 \mathrm{HP}$ Glycol Chiller (Penguin Chillers, Knoxville, TN).

Flow velocity at the pipe wall was estimated using a calibration curve of approximate water velocity vs. motor power (Figure 3-3). The water velocity was confirmed by injecting the reactor with $2 \mathrm{~mL}$ of $125 \mathrm{mg} / \mathrm{L}$ Rhodamine B (Sigma Aldrich) and recording the time required for the dye to travel along a $36 \mathrm{~cm}$ (14”) section of the reactor using a video recording.

The temperature within each PSR was maintained at $12{ }^{\circ} \mathrm{C} \pm 2{ }^{\circ} \mathrm{C}$, based on the average temperature in the Newmarket distribution system, using an Inkbird ITC-308 external temperature controller by recirculating a 50/50 vol/vol mixture of glycol/ distilled water through the stainlesssteel heat exchanger within the reactor. The glycol/ distilled water mixture was cooled to $4{ }^{\circ} \mathrm{C}$ with a 1/2 HP Glycol Chiller (Penguin Chillers, Knoxville, TN). 


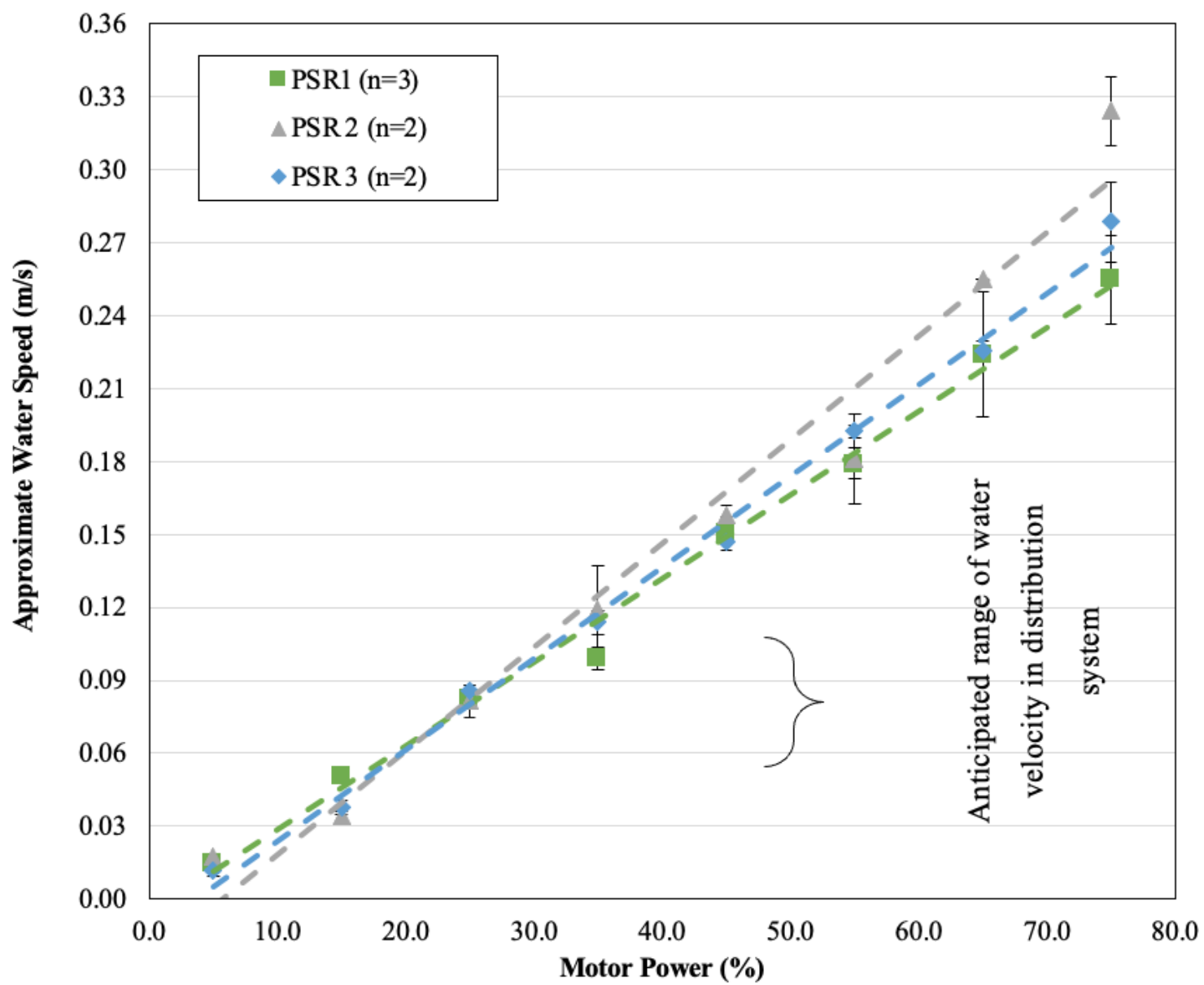

Figure 3-3: Pipe Section Reactor Calibration Curve for approximate water speed (m/s) vs. motor power (\%) for Pipe Section Reactors 1-3.

$\mathrm{N}$ indicates the number of experimental replicates.

\subsection{Water Sampling}

Samples of treated groundwater and surface water were collected from the distribution system using 10-L, blue, high-density polyethylene carboys that did not contribute to chloramine decay. The distribution system examined as part of this study received treated water from both groundwater and surface water sources; a blend of the two sources occurred within parts of the system. Bulk water and PSR trials were conducted separately for each water type, as well as combinations of the two sources. 


\subsection{Milli-Q Water Trials}

To evaluate the efficacy of cleaning and chlorinating PSRs between experimental replicates on mitigating the chloramine decay associated with the Pipe Section Reactor internal components, duplicate $72 \mathrm{~h}$ trials of static monochloramine decay experiments were conducted with acrylic PSRs at $20 \pm 3{ }^{\circ} \mathrm{C}$. Prior to each replicate, the inner and outer acrylic cylinder for each reactor were scrubbed with a solution of diluted bleach and dish soap and then rinsed $2 \mathrm{x}$ with DI water and 1x with Elix water. Next, reactors were filled with Milli-Q and dosed with $2.5 \mathrm{mg} / \mathrm{L}$ monochloramine and monochloramine decay as total chlorine was monitored over $72 \mathrm{~h}$. The firstorder monochloramine decay rate as total chlorine for Milli-Q in chloramine demand-free amber glass bottles at $12 \pm 2{ }^{\circ} \mathrm{C}$ is $8.6 \times 10^{-4} 1 / \mathrm{h}$, as compared to $3.3 \times 10^{-3}, 2.1 \times 10^{-3}$, and $1.6 \times 10^{-3} 1 / \mathrm{h}$ at $20 \pm 3{ }^{\circ} \mathrm{C}$ for PSRs 1-3, respectively (Table 3-1, Figure 3-4A and B). The average $(n=2)$ firstorder monochloramine decay rate as total chlorine for Milli-Q in PSR1 at $12 \pm 2{ }^{\circ} \mathrm{C}$ was found to be $2.8 \times 10^{-3} 1 / \mathrm{h}$ (Table 3-1). The increase of decay rate for PSR 1 from $2.8 \times 10^{-3} 1 / \mathrm{h}$ at $12 \pm 2{ }^{\circ} \mathrm{C}$ to $3.3 \times 10^{-3} 1 / \mathrm{h}$ at $20 \pm 3{ }^{\circ} \mathrm{C}$ may be associated with the temperature increase between experiments.

Table 3-1: Comparison of Zero- and First-Order Total Chlorine Decay Constants for Milli-Q stored in Chloramine Demand-Free (DF) Amber Glass Bottles $\left(12^{\circ} \mathrm{C} \pm 2{ }^{\circ} \mathrm{C}\right)$, in Acrylic PSR1 $\left(12^{\circ} \mathrm{C} \pm\right.$ $\left.2{ }^{\circ} \mathrm{C}\right)$, and in Acrylic PSRs $1-3\left(20^{\circ} \mathrm{C} \pm 3{ }^{\circ} \mathrm{C}\right)$

\begin{tabular}{|c|c|c|c|c|c|}
\hline & $\begin{array}{l}\text { MQ in Chlorine } \\
\text { DF Amber Glass } \\
\text { Bottles at } 12 \pm 2 \\
{ }^{\circ} \mathrm{C}\end{array}$ & $\begin{array}{c}\text { Average MQ PSR } 1 \\
\text { Acrylic Static at } \\
12 \pm 2{ }^{\circ} \mathrm{C} \text { from } \\
\text { Trials } 1-3(\mathrm{n}=2)\end{array}$ & $\begin{array}{c}\text { MQ PSR } 1 \\
\text { Acrylic Static } \\
\text { at } 20 \pm 3^{\circ} \mathrm{C} \\
\quad(n=2)\end{array}$ & $\begin{array}{c}\text { MQ PSR } 2 \\
\text { Acrylic Static } \\
\text { at } 20 \pm 3{ }^{\circ} \mathrm{C} \\
\quad(n=2)\end{array}$ & $\begin{array}{c}\text { MQ PSR } 3 \\
\text { Acrylic Static } \\
\text { at } 20 \pm 3{ }^{\circ} \mathrm{C} \\
\quad(n=2)\end{array}$ \\
\hline $\begin{array}{l}\text { Zero-Order } \\
\text { Decay Rate } \\
\left(\mathrm{mg} \mathrm{L}^{-1} \mathrm{~h}^{-1}\right)\end{array}$ & $2.1 \times 10^{-3}$ & $5.5 \times 10^{-3}$ & $6.7 \times 10^{-3}$ & $4.7 \times 10^{-3}$ & $3.6 \times 10^{-3}$ \\
\hline $\begin{array}{c}\text { First-Order } \\
\text { Decay Rate } \\
\qquad\left(h^{-1}\right)\end{array}$ & $8.6 \times 10^{-4}$ & $2.8 \times 10^{-3}$ & $3.3 \times 10^{-3}$ & $2.1 \times 10^{-3}$ & $1.6 \times 10^{-3}$ \\
\hline
\end{tabular}



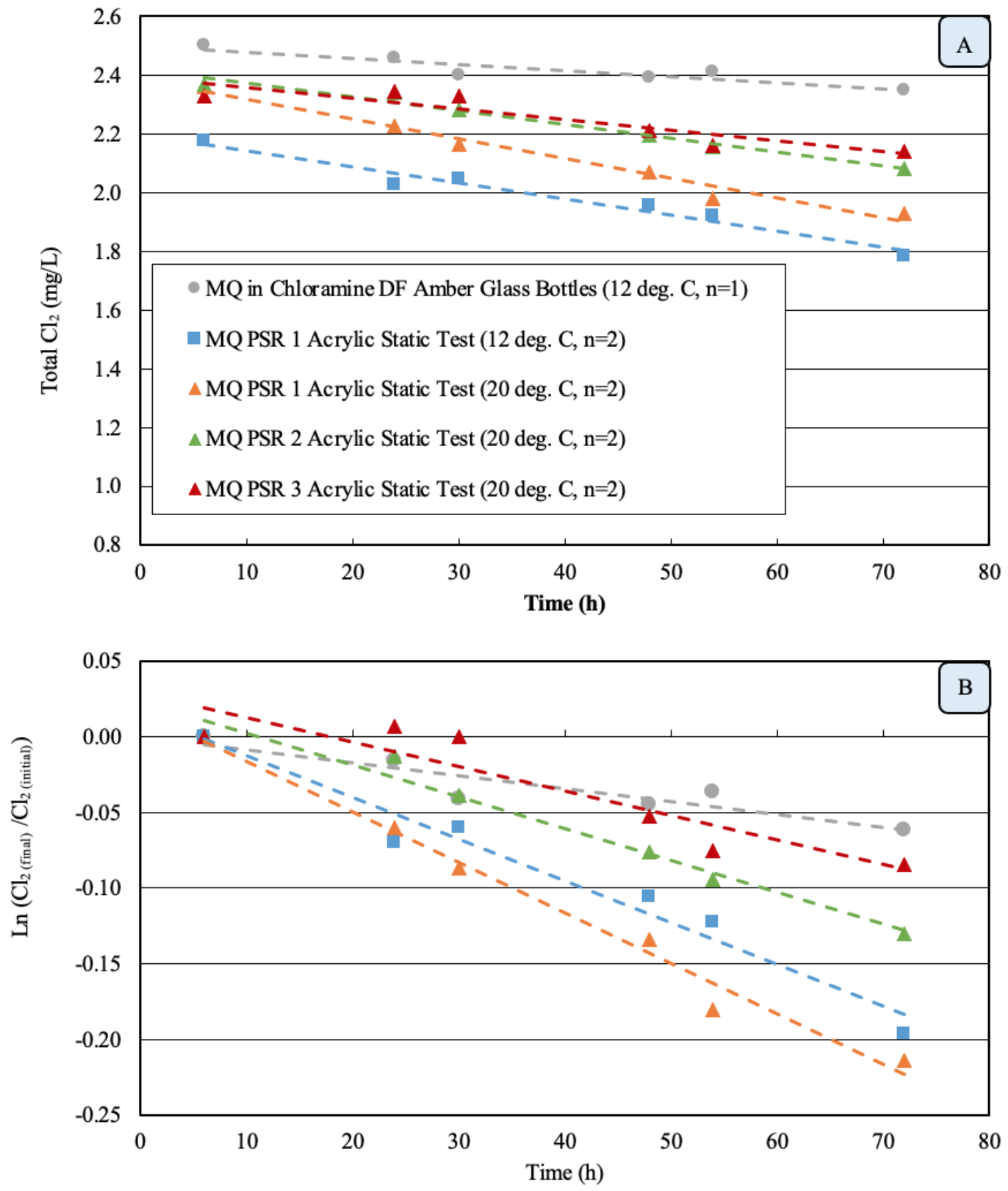

Figure 3-4 A and B: Total Chlorine Decay over 72 hours for Milli-Q (MQ) Water stored in Chloramine Demand-Free (DF) Amber Glass Bottles $\left(12{ }^{\circ} \mathrm{C} \pm 1{ }^{\circ} \mathrm{C}\right)$, in Acrylic PSR $1\left(12{ }^{\circ} \mathrm{C} \pm 1\right.$ ${ }^{\circ} \mathrm{C}$ ), and in Acrylic PSRs 1-3 (20 $\left.{ }^{\circ} \mathrm{C} \pm 3{ }^{\circ} \mathrm{C}\right)$, Fit to Zero- (3-4 A) and First-Order (3-4 B) Model. $\mathrm{N}$ indicates the number of experimental replicates. 


\subsection{Bulk Water Trials}

Batch monochloramine decay trials included the use of amber glass bottles (1-L) that were prepared to be chlorine demand-free by soaking for $24 \mathrm{~h}$ in a solution of $\sim 800 \mathrm{mg} / \mathrm{L}$ chlorine. To evaluate the variation of monochloramine decay associated with a given water source, duplicate samples of surface water, groundwater, and a 50/50 mixture (v/v) were compared to decay in MilliQ® water (representing a very low chloramine demand), which had been buffered to $\mathrm{pH} 8.0$ following dosing with monochloramine to obtain a residual of $2.5 \pm 0.3 \mathrm{mg} / \mathrm{L}$. Samples were maintained at $12{ }^{\circ} \mathrm{C} \pm 2{ }^{\circ} \mathrm{C}$ in a temperature-controlled refrigerator. Milli-Q ${ }^{\circledR}$ water served as a lab blank. Total chlorine, free chlorine, monochloramine, free ammonia, and $\mathrm{pH}$ were measured at $0 \mathrm{~h}, 6 \mathrm{~h}, 24 \mathrm{~h}, 30 \mathrm{~h}, 48 \mathrm{~h}, 54 \mathrm{~h}$, and $72 \mathrm{~h}$ from the same amber glass bottle.

\subsection{Pipe Section Reactor Trials}

In parallel with the bulk chloramine decay trials, decay in the PSRs was evaluated using new PVC, harvested PVC, simulated new cast-iron, and harvested cast-iron, with and without surface deposits. Bulk decay rates were compared to those from PSR trials to isolate the impacts of pipe material, velocity, and pipe wall. PSRs were filled with either $100 \%$ groundwater or $100 \%$ surface water samples, maintained at $12^{\circ} \mathrm{C} \pm 2{ }^{\circ} \mathrm{C}$, and dosed to an initial monochloramine concentration of $2.5 \mathrm{mg} / \mathrm{L}$. A separate 10-L carboy of water, consistent with each water type, was dosed with 2.5 $\pm 0.3 \mathrm{mg} / \mathrm{L}$ monochloramine to replace the volume associated with subsequent sample collection and ensure that the PSR remained headspace-free. PSR trials were conducted with internal water velocities of $0.03 \mathrm{~m} / \mathrm{s}$ or $0.09 \mathrm{~m} / \mathrm{s}$, representing a typical range in the distribution system. Total chlorine, monochloramine, free chlorine, free ammonia, and $\mathrm{pH}$ were monitored at $0,6,24,30$, 48, 54, and $72 \mathrm{~h}$ for PVC PSRs and every hour for $0-6 \mathrm{~h}$ when considering CI PSRs.

\subsection{Calculation of Surface Reaction Rates}

Batch water decay rates were compared to those from PSR experiments to isolate the decay attributed to the internal pipe surface. To this end, the following decay rate constants were calculated and compared: the overall observed first-order decay rate ( $\mathrm{k}_{\mathrm{obs}}$ in $\mathrm{h}^{-1}$ ), the bulk water decay rate $\left(\mathrm{kb}_{\mathrm{b}}\right.$ in $\left.\mathrm{h}^{-1}\right)$, and pipe wall surface reaction rate $\left(\mathrm{k}_{\mathrm{w}}\right.$ in $\left.\mathrm{m} / \mathrm{h}\right)$. 
Overall, the change in concentration $\left(\mathrm{dC} / \mathrm{dt}\right.$ in $\mathrm{M} / \mathrm{h}$ or $\left.\mathrm{mg} \mathrm{L}^{-1} \mathrm{~h}^{-1}\right)$ of monochloramine in a pipe section reactor can be described by the following equation (Westbrook and DiGiano, 2009):

Batch water decay rates were compared to those from PSR experiments to isolate the decay attributed to the internal pipe surface. To this end, the following decay rate constants were calculated and compared: i) the overall observed first-order decay rate (kobs in $\mathrm{h}^{-1}$ ), ii) the bulk water decay rate $\left(\mathrm{k}_{\mathrm{b}}\right.$ in $\left.\mathrm{h}^{-1}\right)$, and iii) the pipe wall surface reaction rate $\left(\mathrm{k}_{\mathrm{w}}\right.$ in $\left.\mathrm{m} / \mathrm{h}\right)$.

Overall, the change in concentration ( $\mathrm{dC} / \mathrm{dt}$ in $\mathrm{M} / \mathrm{h}$ or $\mathrm{mg} \mathrm{L}^{-1} \mathrm{~h}^{-1}$ ) of monochloramine in a pipe section reactor can be described by the following equation (Westbrook and DiGiano, 2009):

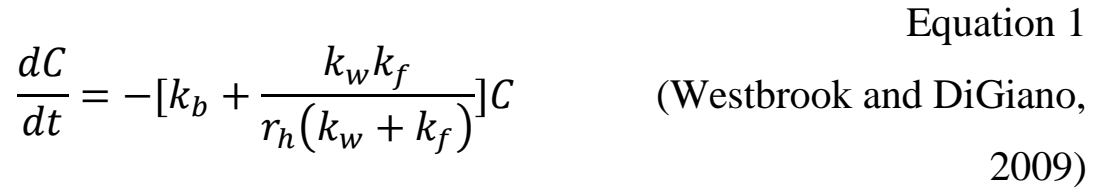

Where: $\quad \mathrm{k}_{\mathrm{b}}$ is the bulk water decay rate in $\mathrm{h}^{-1}$,

$\mathrm{k}_{\mathrm{w}}$ is the surface reaction rate along the pipe wall in $\mathrm{m} / \mathrm{h}$,

$\mathrm{k}_{\mathrm{f}}$ is the mass transfer coefficient in $\mathrm{m} / \mathrm{h}$,

$\mathrm{r}_{\mathrm{h}}$ is the hydraulic radius of the pipe in $\mathrm{m}$, and

$\mathrm{C}$ is the monochloramine concentration in $\mathrm{M}$ or $\mathrm{mg} / \mathrm{L}$.

\subsubsection{Calculation of $\mathrm{k}_{\mathrm{w}}$ for Cast-Iron Pipe (Mass Transfer Dependent on Internal Velocity)}

Westbrook and DiGiano (2009) have previously shown that the pipe wall surface reaction rate for first-order chloramine decay in a cast-iron pipe section reactor could be calculated using the following equation, in which kobs is the overall observed first-order decay rate in $\mathrm{h}^{-1}$ :

$$
k_{w}=\frac{\left(k_{o b s}-k_{b}\right) r_{h} k_{f}}{k_{f}-r_{h}\left(k_{o b s}-k_{b}\right)}
$$

Equation 2

(Westbrook and DiGiano,

First, $\mathrm{kf}_{\mathrm{f}}$ was calculated to solve for kw. Mobarak et al. (1997) and Westbrook and DiGiano (2009) provide the following equation for $\mathrm{kf}_{\mathrm{f}}$ in an annular pipe segment:

$$
k_{f}=\frac{D}{d} 0.167 S c^{0.33} \operatorname{Re}\left(\frac{L}{D}\right)^{-0.472}\left(\frac{e}{d}\right)^{0.33}
$$


Where: $\quad \mathrm{kb}$ is the bulk water decay rate in $\mathrm{h}^{-1}$,

$D$ is the molecular diffusivity of monochloramine in water in $\left(4.10 \times 10^{-6} \mathrm{~m}^{2} / \mathrm{h}\right)$

estimated from (Lyman et al., 1990; Liu et al., 2015),

$\mathrm{d}$ is the hydraulic diameter of the pipe in $\mathrm{m}$,

Sc is the Schmidt number and is unitless,

$\mathrm{Re}$ is the Reynolds number and is unitless,

$\mathrm{L}$ is the length of the annulus in $\mathrm{m}$,

$\mathrm{e}$ is the pipe roughness in $\mathrm{m}$.

By substituting Equation 3 into Equation 2, $\mathrm{k}_{\mathrm{w}}$ was calculated for the cast-iron PSRs.

\subsubsection{Calculation of $\mathrm{k}_{\mathrm{w}}$ for PVC Pipe (Mass Transfer Independent of Internal Velocity)}

Since little change in the first-order observed decay rate (kobs) was observed when increasing the internal velocity for PVC pipe, mass transfer did not depend on velocity, and $\mathrm{k}_{\mathrm{w}}$ could be calculated using the following equation, adapted from Westbrook and DiGiano (2009):

$$
k_{w}=r_{h}\left(k_{o b s}-k_{b}\right)
$$

Equation 4

\subsection{Analytical Methods}

\subsubsection{Water Quality}

$\mathrm{pH}$ was measured with an Orion Star A111 pH meter (Thermo Fisher, Mississauga, Ontario). Monochloramine stock was prepared according to a modified method from Mitch and Sedlack (2002) by using $1 \mathrm{M}$ sodium borate buffer instead of sodium hydroxide. Total chlorine, free chlorine, and monochloramine concentrations were determined spectrophotometrically using HACH DR 2700 and DR 2500 spectrophotometers and powder pillows (London, Ontario). Free ammonia concentrations were assessed using the following equipment from Fisher Scientific (Whitby, Ontario): a Fisherbrand ${ }^{\mathrm{TM}}$ accumet $^{\mathrm{TM}}$ Gas-Sensing Combination Ion-Selective Electrode (13-620-509), accumet ${ }^{\mathrm{TM}}$ Ammonia $\mathrm{pH} /$ Ionic Strength Adjustor (13-620-802), and a Fisherbrand ${ }^{\mathrm{TM}}$ accumet $^{\mathrm{TM}}$ AP125 portable $\mathrm{pH} / \mathrm{Ion} / \mathrm{mV} / \mathrm{Temperature}$ meter. DO was measured using a YSI 500A dissolved oxygen meter (Yellow Springs, Ohio, USA), and ORP and conductivity were measured with a HACH sensION MM150 meter (London, Ontario). DOC was 
determined by first vacuum filtering samples using 0.45 -micron polyethersulfone filter paper (Pall

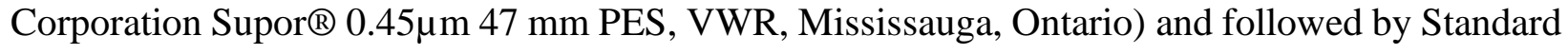
Method 5310 D persulfate wet oxidation as described in APHA et al. (2012) with an O-I Analytical Model 1030 Wet Oxidation Total Organic Carbon Analyzer with a Model 1088 Autosampler (College Station, Texas, USA).

\subsubsection{Dissolved Organic Carbon (DOC)}

DOC concentrations were determined via Standard Method 5310 D persulfate wet oxidation as described in APHA et al., 2012 using a Model 1030 Wet Oxidation Total Organic Carbon Analyzer with Model 1088 Autosampler from OI Corporation (College Station, Texas, USA). First, samples were vacuum filtered through a $0.45 \mu \mathrm{m}$ polyethersulfone filter and transferred to $40 \mathrm{~mL}$ amber glass vials with Teflon ${ }^{\circledR}$-lined septum caps. If samples were not analyzed immediately, they were acidified to $\mathrm{pH} \leq 2$ with sulphuric acid (VWR International, 98\%+) and stored at $4{ }^{\circ} \mathrm{C}$ for 14 days or fewer. Calibration standards were prepared with anhydrous potassium hydrogen phthalate (KHP, Sigma Aldrich, 98\%+) diluted with Milli-Q ® water. A $10 \mathrm{mg} / \mathrm{L}$ KHP stock was prepared and then diluted to create a calibration curve with concentrations of $0,0.625,1.25,2.5,5 \mathrm{mg} / \mathrm{L}$ KHP. Throughout sample analysis, a Milli-Q® blank and check $(2.5 \mathrm{mg} / \mathrm{L})$ standard were included every 10 samples and at the end of the sample run. Additionally, for quality assurance and quality control, three blanks were placed after the calibration solutions. Figure 3-5 provides an example calibration curve prepared in January 2020.

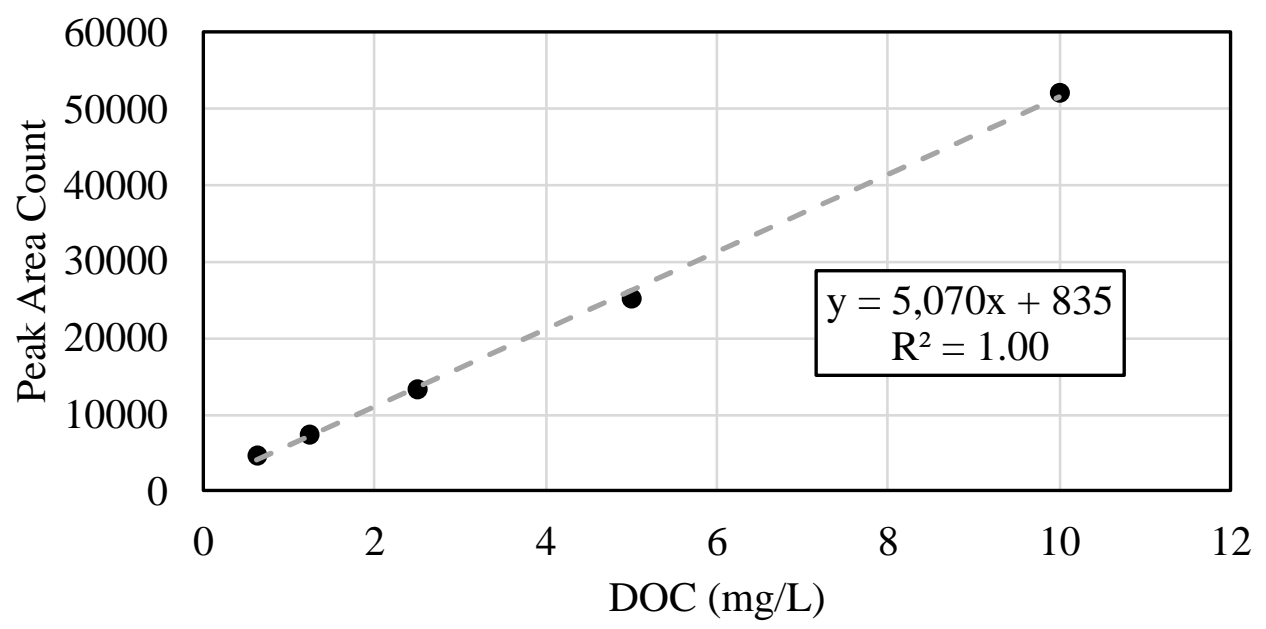

Figure 3-5: DOC Calibration Curve (January 2020) 
The DOC analyzer was run with $200 \mu \mathrm{L}$ of $5 \%$ phosphoric acid (Caledon, $>85 \%$ ) and $1000 \mu \mathrm{L}$ of $100 \mathrm{~g} / \mathrm{L}$ sodium persulphate (Sigma Aldrich, 98\%+, anhydrous) with $15 \mathrm{~mL}$ sample and rinse volumes, 1 rinse per sample, and 3 replicates per sample. Nitrogen (Praxair, Ultra-high purity (UHP)) was used as the purge gas, and the loop size was $5 \mathrm{~mL}$. The reaction times and detection times for total inorganic carbon were 2 minutes and 2 minutes and 40 seconds and were 2 minutes and 30 seconds and 2 minutes for total organic carbon.

\subsection{3 $\mathrm{UV}_{254}$}

$\mathrm{UV}_{254}$, or the ultraviolet light absorbance at $254 \mathrm{~nm}$, is an estimate of water samples' organic content (Kitis et al., 2002). UV 254 analysis was conducted using a Cecil Instruments - CE 3055 UV/Vis Spectrophotometer (Cambridge, England) using a quartz cuvette with $1 \mathrm{~cm}$ path length (Hewlett Packard, Mississauga, Ontario). Prior to sample analysis, a Milli-Q® blank was used to zero the spectrophotometer; between samples, the quartz cuvette was rinsed twice with Milli-Q ${ }^{\circledR}$ and once with the sample. Specific UV Absorbance (SUVA) is the quotient of $\mathrm{UV}_{254}$ and DOC concentration (Potter and Wimsatt, 2005). 


\section{Chapter 4: Results}

\section{$4 \quad$ Results}

\subsection{Batch Trials: Impact of Bulk Water Source on Chloramine Decay}

\subsubsection{Distribution System Water Quality}

Temperature and $\mathrm{pH}$ were similar for the surface water and groundwater $\left(10.8^{\circ} \mathrm{C}\right.$ and $10.3^{\circ} \mathrm{C}, 7.5$ and 7.8, respectively, Table 4-1); however, DOC was typically higher in the surface water (1.6 $\mathrm{mg} / \mathrm{L})$ when compared to groundwater $(0.9 \mathrm{mg} / \mathrm{L})$. When considering samples collected for parallel batch and PSR trials, surface water had higher DO, higher ORP, lower UV 254 absorbance, and lower SUVA than groundwater (Table 4-2). Based on DOC alone, higher decay would be anticipated for surface water; however, this was true for groundwater $\left(9.2 \times 10^{-3} \mathrm{mg} \mathrm{L}^{-1} \mathrm{~h}^{-1}\right)$, as shown in Figure 4-1A-C and Table 4-3. One possible explanation is that the surface and groundwater were chloraminated prior to entering the distribution system, and as such, initial chloramine demand was satisfied prior to batch and PSR trials. In contrast, SUVA was higher for groundwater, suggesting that it may serve as a better indicator of demand. Moradi et al. (2017) used SUVA, along with microbiological activity and initial chloramine concentration, to predict chloramine decay. As anticipated, pH, DOC, UV 254 absorbance, and SUVA values for the 50/50 blend fell between those for ground and surface water. As such, demand associated with the bulk water was likely not the primary source of chloramine decay.

Table 4-1: Water quality parameters for initial batch water trials.

\begin{tabular}{cccc}
\hline Parameter & \multicolumn{2}{c}{ Source } \\
\cline { 2 - 4 } & Groundwater & $50 \%$ Groundwater/ 50\% Surface Water & $\begin{array}{c}\text { Surface } \\
\text { Water }\end{array}$ \\
\hline pH & 10.8 & Not applicable; the sample was prepared & 10.3 \\
Temperature (upon collection, $\left.{ }^{\circ} \mathrm{C}\right)$ & in the lab & 7.8 \\
DOC (mg/L) & 7.5 & 7.8 & 1.6 \\
$\mathrm{UV}_{254}$ absorbance $\left(\mathrm{cm}^{-1}\right)$ & 0.9 & 1.3 & 0.029 \\
Specific UV & 0.075 & 0.052 & 1.3 \\
$(\mathrm{~L} / \mathrm{mg}-\mathrm{m})$ & 4.2 & 4.0 & \\
\hline
\end{tabular}


Table 4-2: Average Water Quality Values for Groundwater and Surface Water in PSR Trials. Note: Samples were collected over a 5-month period - averages based on $n=7$ for groundwater and $\mathrm{n}=2$ for surface water.

\begin{tabular}{ccc}
\hline & \multicolumn{2}{c}{ Source } \\
\cline { 2 - 3 } Parameter & Groundwater & $\begin{array}{c}\text { Surface Water average } \\
(\mathrm{min}, \mathrm{max})\end{array}$ \\
\hline Dissolved Oxygen $(\mathrm{mg} / \mathrm{L})$ & $2 \pm 1$ & $6.6(2.5,11)$ \\
Temperature $\left({ }^{\circ} \mathrm{C}\right)$ & $10.6 \pm 0.6$ & $10.3(5.35,15.3)$ \\
$\mathrm{pH}$ & $7.6 \pm 0.1$ & $7.6(7.5,7.7)$ \\
Free chlorine $(\mathrm{mg} / \mathrm{L})$ & $0.06 \pm 0.02$ & $0.09(0.08,0.10)$ \\
Total chlorine $(\mathrm{mg} / \mathrm{L})$ & $2.4 \pm 0.2$ & $3.0(2.9,3.1)$ \\
Monochloramine $(\mathrm{mg} / \mathrm{L})$ & $2.2 \pm 0.2$ & $2.8(2.6,2.9)$ \\
Oxidation-reduction potential $(\mathrm{ORP})(\mathrm{mV})$ & $590 \pm 60$ & $400(380,420)$ \\
Conductivity $(\mu \mathrm{S} / \mathrm{cm})$ & $45 \pm 60$ & $410(340,480)$ \\
$\mathrm{UV}_{254}$ absorbance $\left(\mathrm{cm}{ }^{-1}\right)$ & $0.075 \pm 0.005$ & $0.029(0.025,0.032)$ \\
Dissolved Organic Carbon $(\mathrm{DOC})(\mathrm{mg} / \mathrm{L})$ & $2.2 \pm 0.9$ & $2.6(1.6,3.6)$ \\
Specific $\mathrm{UV}_{254}$ absorbance $(\mathrm{SUVA})(\mathrm{L} / \mathrm{mg}-\mathrm{m})$ & $4 \pm 2$ & $1.3(0.9,1.6)$ \\
\hline
\end{tabular}

\subsubsection{Bulk Water Chloramine Decay}

Although the autodecomposition of chloramine has been well-described by a second-order model in controlled laboratory trials (Valentine et al., 1998), chloramine decay in distribution systems may involve a number of reaction mechanisms, which empirically follow a first-order model (Westbrook and DiGiano, 2009; Vasconcelos et al., 1997). For this reason, first and second-order chloramine decay rates (as total chlorine) were calculated; zero-order decay (as total chlorine) is also plotted for reference to help contextualize changes in chloramine concentration with respect to time (Figure 4-1A-C, Table 4-3).

Limited decay $(<10 \%)$ was associated with Mill-Q @ water (total chlorine concentration $>2.25$ $\mathrm{mg} / \mathrm{L}$ after $72 \mathrm{~h}$ ), which was used as a system blank; little to no chloramine demand was associated with the amber glass bottles or analytical equipment. High chloramine residuals (> $1.5 \mathrm{mg} / \mathrm{L})$ were observed in all three bulk water samples following 72 hours, which exceeds the minimum chloramine residual of $0.25 \mathrm{mg} / \mathrm{L}$ required by O. Reg. 170/03 "Drinking Water Systems" and falls below the maximum concentrations of $3 \mathrm{mg} / \mathrm{L}$ or $4 \mathrm{mg} / \mathrm{L}$ dictated by the World Health 
Organization (2017) and the USEPA (1998), respectively (Figure 4-1A-C). Concentrations of >1.5 mg/L are suggested by Health Canada (2018), while the USEPA (1994) and World Health Organization (2017) suggest distribution system chloramine concentrations of 1.5-2.5 mg/L and 0.5-2.0 mg/L, respectively. Decay rates observed in bulk water may be lower than typically anticipated since all waters were chloraminated prior to collection.

Surface water had a first-order decay constant $\left(1.9 \times 10^{-3} \mathrm{~h}^{-1}\right)$ that fell among those reported by Zhang et al. (2017), Westbrook and DiGiano (2009), Ozdemir and Demir (2007), and DiGiano and Zhang (2005), suggesting that decay rates within this range may be expected for other distribution systems which convey treated surface water (Table 4-3). Since groundwater was observed to demonstrate the highest decay, pipe section reactor trials were primarily conducted with this water type to assess "worst-case" residual decay in the distribution system.
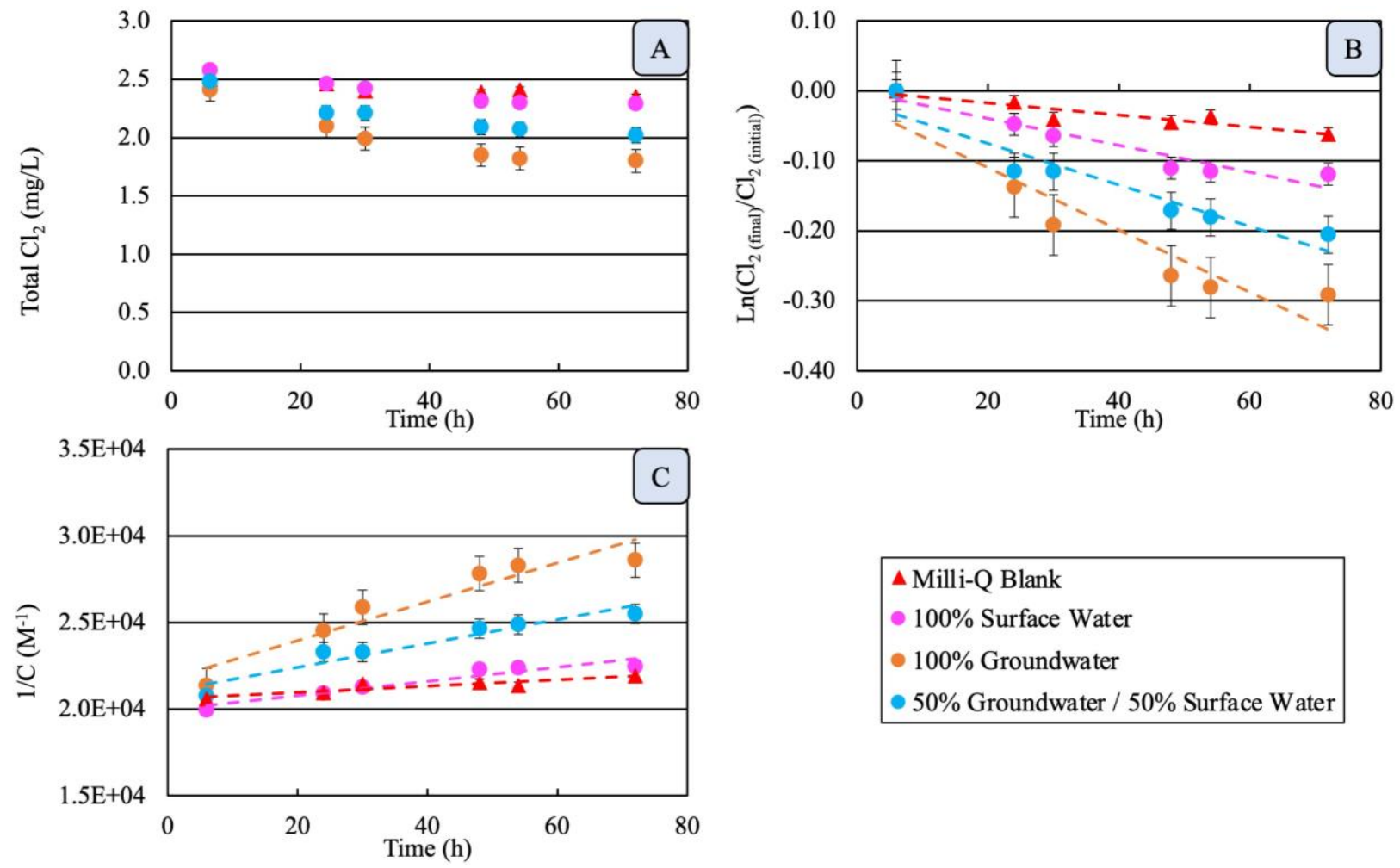

Figure 4-1A-C: Batch Monochloramine Decay at $12{ }^{\circ} \mathrm{C} \pm 2{ }^{\circ} \mathrm{C}$ (as Total Chlorine) Fit to Zero (4-1A), First (4-1B), and Second Order (4-1C) Models.

Note: Vertical bars indicate one standard deviation $(n=3)$. 
Table 4-3: Comparing Zero, First and Second-Order Total Chlorine Bulk Water Decay Constants from the Present Study to those from the Literature

\begin{tabular}{|c|c|c|c|c|c|c|c|c|c|c|c|c|}
\hline Study & $\begin{array}{c}\text { Secondary } \\
\text { Disinfectant }\end{array}$ & Water Source & $\begin{array}{c}\text { Zero- } \\
\text { order } \\
\text { decay } \\
\text { constant } \\
\left(\mathrm{mg} \mathrm{L}^{-1} \mathrm{~h}^{-1}\right. \\
\left.\mathrm{x} 10^{-3}\right) \\
\end{array}$ & $\begin{array}{l}\text { Zero- } \\
\text { order } \\
\mathrm{R}^{2}\end{array}$ & $\begin{array}{c}\text { First- } \\
\text { order } \\
\text { decay } \\
\text { constant } \\
\left(\mathrm{h}^{-1} \mathrm{x}\right. \\
\left.10^{-3}\right)\end{array}$ & $\begin{array}{l}\text { First- } \\
\text { order } \\
\mathrm{R}^{2}\end{array}$ & $\begin{array}{l}\text { Second- } \\
\text { order } \\
\text { decay } \\
\text { constant } \\
\left(\mathrm{M}^{-1} \mathrm{~h}^{-1}\right)\end{array}$ & $\begin{array}{l}\text { Second- } \\
\text { order } \mathrm{R}^{2}\end{array}$ & $\begin{array}{c}\mathrm{DO} \\
(\mathrm{mg} / \mathrm{L})\end{array}$ & $\begin{array}{l}\text { Initial } \\
\text { Chlorine } \\
(\mathrm{mg} / \mathrm{L})\end{array}$ & $\begin{array}{l}\text { Temperature } \\
\left({ }^{\circ} \mathrm{C}\right)\end{array}$ & $\mathrm{pH}$ \\
\hline \multirow{2}{*}{$\begin{array}{l}\text { Vikesland } \\
\text { et al. } \\
(2001) \\
\end{array}$} & \multirow[b]{2}{*}{ Chloramine } & Groundwater & $2^{a}$ & NR & NR & NR & NR & NR & NR & 2.7 & \multirow[b]{2}{*}{25} & 8.3 \\
\hline & & Surface water & $2-5^{a}$ & NR & NR & NR & NR & NR & NR & $2.2-2.7$ & & $\begin{array}{l}7.9- \\
8.3 \\
\end{array}$ \\
\hline \multirow{3}{*}{$\begin{array}{l}\text { Present } \\
\text { study }\end{array}$} & \multirow{3}{*}{ Chloramine } & Groundwater & 9.2 & 0.91 & 4.5 & 0.88 & 110 & 0.90 & 3.9 & 2.5 & 12 & $\begin{array}{l}7.5- \\
8.0\end{array}$ \\
\hline & & $\begin{array}{c}50 \% \\
\text { groundwater/ } \\
50 \% \text { surface } \\
\text { water }\end{array}$ & 6.6 & 0.88 & 3.0 & 0.90 & 69 & 0.91 & 8.7 & 2.5 & 12 & $\begin{array}{l}7.8- \\
8.1\end{array}$ \\
\hline & & Surface water & 4.6 & 0.86 & 1.9 & 0.91 & 41 & 0.92 & 10.7 & 2.5 & 12 & $\begin{array}{l}7.6- \\
8.2\end{array}$ \\
\hline $\begin{array}{l}\text { Westbrook } \\
\text { and } \\
\text { DiGiano } \\
(2009)\end{array}$ & Chloramine & Surface water & NR & NR & $\begin{array}{l}0.17- \\
0.30\end{array}$ & $\begin{array}{c}0.73- \\
0.99\end{array}$ & $2.7-10.0$ & $\begin{array}{c}0.96- \\
0.99\end{array}$ & $\begin{array}{c}8.9 \\
\text { (average) }\end{array}$ & $2.0-4.3$ & 25 & $\begin{array}{l}7.9- \\
8.5\end{array}$ \\
\hline $\begin{array}{l}\text { Ozdemir } \\
\text { and Demir } \\
(2007)\end{array}$ & $\begin{array}{c}\text { Free } \\
\text { Chlorine }\end{array}$ & $\begin{array}{c}\text { Primarily } \\
\text { surface water } \\
\text { (Bakir et al., } \\
\text { 2003) }\end{array}$ & NR & NR & $20-55$ & $\begin{array}{c}0.92- \\
1.0\end{array}$ & NR & NR & NR & $0.05-0.5$ & NR & NR \\
\hline $\begin{array}{c}\text { DiGiano } \\
\text { and Zhang } \\
(2005)\end{array}$ & $\begin{array}{c}\text { Free } \\
\text { Chlorine }\end{array}$ & Surface water & NR & NR & $26-38$ & NR & NR & NR & $7-8.5$ & $\begin{array}{l}1.02- \\
1.28\end{array}$ & 21 & $\begin{array}{l}7.3- \\
7.7\end{array}$ \\
\hline $\begin{array}{l}\text { Zhang et al. } \\
\qquad(2017)\end{array}$ & $\begin{array}{c}\text { Free } \\
\text { Chlorine }\end{array}$ & NR & NR & NR & $21-61$ & NR & NR & NR & NR & $\begin{array}{c}0.30- \\
0.40\end{array}$ & 15 & 7.0 \\
\hline
\end{tabular}

$\mathrm{NR}=$ Not Reported

$\mathrm{a}=$ estimated from graphical results. 


\subsection{Impact of Pipe Material and Flow Regime}

\subsubsection{Decay Associated with Distribution System Pipe Material}

Batch water decay rates were compared to those from PSR trials in order to evaluate decay associated with pipe wall reactions (Figure 4-2A and B). Results from batch and PSR experiments using groundwater are highlighted as having the highest decay rate (Figure 4-2A and B). Chloramine decay (as total chlorine) for both the bulk water and PSRs fit a first-order model $\left(\mathrm{R}^{2}\right.$ 0.84-0.98), indicating that the decay was linear with the chloramine concentration, as reported by Westbrook and DiGiano (2009) (Figure 4-2B, Table 4-4). Although trials in the present study were conducted with an initial chloramine concentration of approximately $2.5 \mathrm{mg} / \mathrm{L}$, Westbrook and DiGiano (2009) reported first-order decay rates to be similar for initial chloramine concentrations of $1.7-3.8 \mathrm{mg} / \mathrm{L}$, suggesting that initial concentration may not impact decay rate. Chloramine decay was also fit to a zero-order model and plotted for reference (Figure 4-2A).

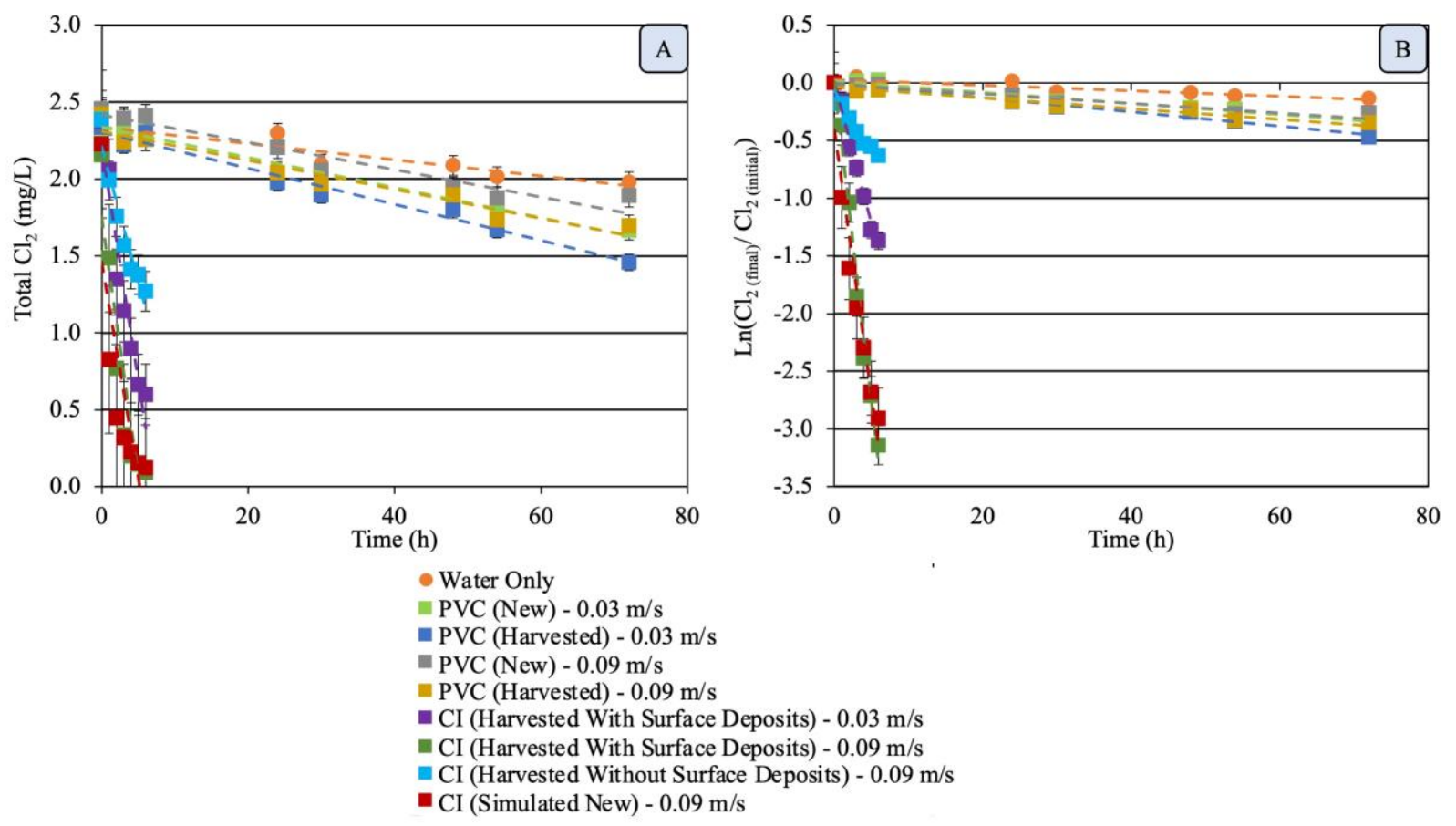

Figure 4-2A and B: Monochloramine Decay (Total Chlorine) for Groundwater Batch and PSR Experiments, Fit to Zero-Order Model (4-2A) and First-Order Model (4-2B) - Maintained at 12 ${ }^{\circ} \mathrm{C} \pm 2{ }^{\circ} \mathrm{C}$.

Average results from duplicate trials. Vertical bars indicate one standard deviation. 
First-order decay associated with PVC or CI pipe in PSR trials increased substantially (PVC, 40$230 \%$ increase in kobs $\left.8.3 \times 10^{-2}-7.8 \times 10^{-3} \mathrm{~h}^{-1}\right)$ when compared to bulk water $\left(2.4 \times 10^{-3} \mathrm{~h}^{-1}\right)$, for CI an increase of 3,400-30,000\% in kobs $\left(1.0 \times 10^{-1}-7.2 \times 10^{-1} \mathrm{~h}^{-1}\right)$. Kiéné et al. (1998), Menaia et al. (2003), and Hallam et al. (2002) reported nominal free chlorine decay associated with the PVC pipe material itself. However, increased decay associated with PVC pipe is likely attributable to chloramine reactions with deposited materials along the pipe wall according to free chlorine decay data reported by Kiéné et al. (1998). Accelerated chloramine decay has been reported by others as being related to reactions with ferrous iron along pipe walls (Woolschlager et al., 2001; Pirou et al., 1997)

In addition to the overall observed first-order reaction rate constant (kobs), the surface reaction rate constant $\left(\mathrm{k}_{\mathrm{w}}\right)$ is shown for each pipe type. Figure 4-3A and B provide kobs and $\mathrm{k}_{\mathrm{w}}$ for PSR experiments with groundwater and surface water at $0.03 \mathrm{~m} / \mathrm{s}$ and $0.09 \mathrm{~m} / \mathrm{s}$. Overall, $\mathrm{k}_{\text {obs }}$ and $\mathrm{k}_{\mathrm{w}}$ were highest for cast-iron pipe, regardless of water type or velocity. Pipe type was the dominant contributor to observed chloramine decay (Figure 4-2A, Figure 4-2B, Figure 4-3A, and Figure 4-3B).

First-order observed decay rates (kobs) for PVC pipe were approximately $100 \%$ higher than those observed for bulk water alone. PVC first-order $\mathrm{k}_{\mathrm{obs}}$ and $\mathrm{k}_{\mathrm{w}}$ values $\left(3.4 \times 10^{-3}-6.2 \times 10^{-3} \mathrm{~h}^{-1}\right.$ and $\left.2.0 \times 10^{-5}-5.2 \times 10^{-5} \mathrm{~m} / \mathrm{h}\right)$ were much lower than for CI $\left(0.10-0.56 \mathrm{~h}^{-1}\right.$ and $1.3 \times 10^{-3}-$ $\left.9.0 \times 10^{-3} \mathrm{~m} / \mathrm{h}\right)$. The highest chloramine decay rates were associated with cast iron pipe, irrespective of flow velocity (Figure 4-2A, Figure 4-2B, Figure 4-3A, and Figure 4-3B). Accelerated cast-iron decay is typically attributable to chloramine reactions with $\mathrm{Fe}^{2+}$ and unlined CI pipe (Clark and Haught, 2005). Pipe material, specifically cast-iron, was the most significant contributor to decay and resulted in the highest $\mathrm{k}_{\mathrm{w}}$ values in the present study, ranging from $1.3 \mathrm{x}$ $10^{-3}$ to $9.0 \times 10^{-3} \mathrm{~m} / \mathrm{h}$ (Table $4-4$ ). As such, mass transfer and surface reactions at the pipe wall contribute significantly to chloramine decay (Table 4-4). However, since $\mathrm{k}_{\mathrm{f}}$ is an order of magnitude greater than $\mathrm{k}_{\mathrm{w}}$, the mass transfer of chloramine to the surface of the cast-iron pipe wall limits the overall observed chloramine decay rates. Similar trends have been reported by others; however, their results were approximately one order of magnitude higher, likely due to differences in water quality, especially temperature, when considering chloramine and free chlorine decay rates in distribution systems (Westbrook and DiGiano, 2009; DiGiano and Zhang, 2005). 


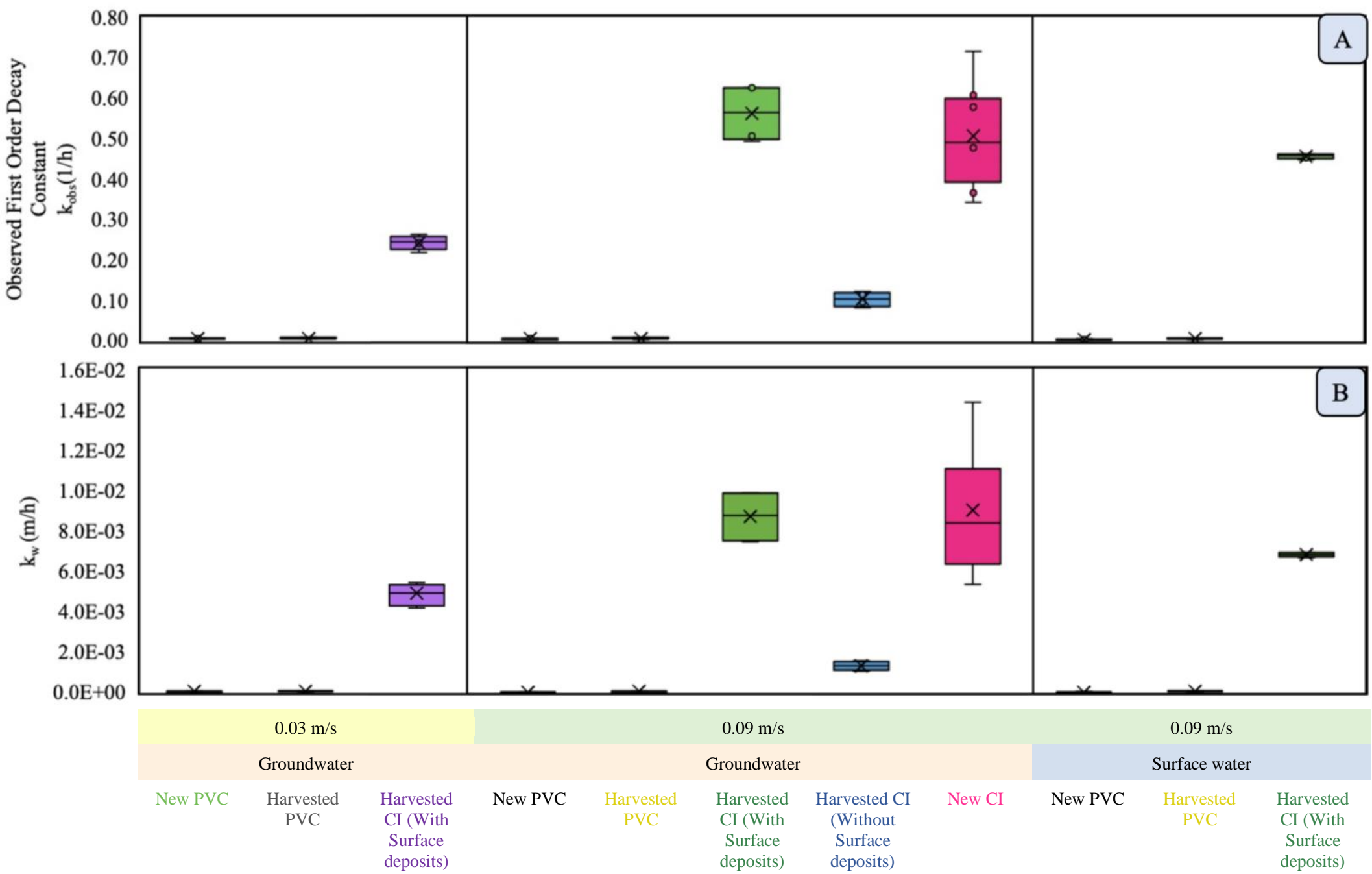

Figure 4-3A and B: Comparison of Observed First-Order Reaction Rate Constants (kobs, 4-3A) and Surface Reaction Rate Constants (kw 4-3B) for Ground and Surface Waters $\left(12^{\circ} \mathrm{C} \pm 2^{\circ} \mathrm{C}\right)$.

Vertical bars span the highest and lowest observations. Boxes indicate quartiles, o indicates outliers, and X represents the mean. 
Table 4-4: Comparison of reduction in chlorine concentration - present study and published literature

\begin{tabular}{|c|c|c|c|c|c|c|c|c|c|c|}
\hline Source & $\begin{array}{c}\% \text { reduction in } \\
\text { chlorine } \\
\text { concentration after } \\
2 \mathrm{~h}\end{array}$ & $\begin{array}{c}\text { First- } \\
\text { Order } \\
\mathrm{k}_{\mathrm{b}} \times 10^{-3} \\
\left(\mathrm{~h}^{-1}\right) \\
\end{array}$ & $\begin{array}{c}\mathrm{k}_{\mathrm{W}} \mathrm{X} \\
10^{-3} \\
(\mathrm{~m} / \mathrm{h})\end{array}$ & $\begin{array}{l}\mathrm{k}_{\mathrm{f}} \\
\mathrm{X} 10^{-2} \\
(\mathrm{~m} / \mathrm{h})\end{array}$ & Pipe Material & Water Type & $\begin{array}{c}\text { Temperature } \\
\left({ }^{\circ} \mathrm{C}\right)\end{array}$ & $\begin{array}{c}\text { Water } \\
\text { Velocity } \\
(\mathrm{m} / \mathrm{s})\end{array}$ & $\mathrm{pH}$ & $\begin{array}{c}\text { Initial total } \\
\text { chlorine } \\
\text { concentration } \\
(\mathrm{mg} / \mathrm{L})\end{array}$ \\
\hline \multirow{5}{*}{ Present study } & 26 & 4.6 & 1.3 & 4.8 & $\begin{array}{c}\text { Cast-iron } \\
\text { (harvested } \\
\text { without surface } \\
\text { deposits) }\end{array}$ & Groundwater & 12 & 0.09 & $\begin{array}{r}7.8- \\
8.2\end{array}$ & 2.5 \\
\hline & 43 & 2.2 & 4.9 & 0.9 & $\begin{array}{c}\text { Cast-iron } \\
\text { (harvested with } \\
\text { surface deposits) }\end{array}$ & Groundwater & 12 & 0.03 & $\begin{array}{l}7.6- \\
7.8\end{array}$ & 2.5 \\
\hline & 65 & 2.6 & 8.7 & 4.8 & $\begin{array}{c}\text { Cast-iron } \\
\text { (harvested with } \\
\text { surface deposits) }\end{array}$ & Groundwater & 12 & 0.09 & $\begin{array}{l}7.5- \\
7.9\end{array}$ & 2.5 \\
\hline & 81 & 1.7 & 9.0 & 2.7 & Cast-iron (new) & Groundwater & 12 & 0.09 & $\begin{array}{l}7.6- \\
7.8\end{array}$ & 2.5 \\
\hline & 82 & 1.3 & 6.8 & 4.8 & $\begin{array}{c}\text { Cast-iron } \\
\text { (harvested with } \\
\text { surface deposits) }\end{array}$ & $\begin{array}{c}\text { Surface } \\
\text { water }\end{array}$ & 12 & 0.09 & $\begin{array}{l}7.6- \\
8.1\end{array}$ & 2.5 \\
\hline \multirow{3}{*}{$\begin{array}{c}\text { Westbrook } \\
\text { and DiGiano } \\
(2009)\end{array}$} & NR & $\begin{array}{c}0.17- \\
0.30\end{array}$ & NR & NR & NR & \multirow[b]{2}{*}{$\begin{array}{c}\text { Surface } \\
\text { water }\end{array}$} & \multirow[b]{2}{*}{22.5} & NR & $\begin{array}{l}7.9- \\
8.5\end{array}$ & $2.0-4.3$ \\
\hline & & & 20 & 12.0 & & & & 0.07 & \multirow{2}{*}{8} & \multirow{2}{*}{$>3.5$} \\
\hline & & & 40 & 72.5 & & & & 0.41 & & \\
\hline
\end{tabular}




\subsubsection{Impact of Harvested Pipe}

When considering PVC trials for the same water type and velocity, harvested pipe was associated with higher first-order kobs and $\mathrm{k}_{\mathrm{w}}$ values (1.1-1.3 and 1.5-2.0 times as high, respectively, Table 4-4) when compared to new pipe. For CI trials with groundwater at $0.09 \mathrm{~m} / \mathrm{s}, \mathrm{k}_{\mathrm{obs}}$ and $\mathrm{k}_{\mathrm{w}}$ for pipe with surface deposits were 5.5 and 6.6 times as high as those for pipe without surface deposits. These results suggest that targeting surface deposit removal in the distribution system may reduce chloramine decay since biofilm and deposited materials are known contributors to chloramine demand (Xue et al., 2014).

Observed decay rates with groundwater at $0.09 \mathrm{~m} / \mathrm{s}$ for new $\mathrm{CI}\left(0.5 \pm 0.1 \mathrm{~h}^{-1}, 3.9 \mathrm{~h}\right.$ to reach 0.25 $\mathrm{mg} / \mathrm{L}$ residual) were similar to those for harvested $\mathrm{CI}$ with surface deposits $\left(0.6 \pm 0.1 \mathrm{~h}^{-1}\right.$, Table 4-4); for CI pipe, aging and the formation of scale along the interior surface may alter chlorine stability, as the chlorine may react more quickly with new cast-iron pipe compared to that which was harvested (Sarin et al., 2004). In this study, all first-order cast-iron decay rates were substantially higher than those for PVC (by 1000 - 30,000\%; $360-610$ h to reach $0.25 \mathrm{mg} / \mathrm{L}$ residual in PVC PSR trials). As such, alternative asset management strategies may be of interest, which include lining cast iron pipe via cured-in-place piping.

\subsubsection{Impact of Flow Velocity}

Only a limited impact of varying water surface velocity $(0.03$ to $0.09 \mathrm{~m} / \mathrm{s})$ was observed for PVC PSR trials, suggesting that surface reactions were rate-limiting and mass transfer was not. Westbrook and DiGiano (2009) reported similar observations for monochloramine PSR trials using cement-lined ductile iron pipe, which, along with PVC, is considered to be less reactive than CI (Hallam et al., 2002).

For PSR trials with harvested CI pipe containing surface deposits, kobs and $\mathrm{k}_{\mathrm{w}}$ at $0.03 \mathrm{~m} / \mathrm{s}$ were 2.3 and 1.8 times those at $0.03 \mathrm{~m} / \mathrm{s}(360-470 \mathrm{~h}$ to reach $0.25 \mathrm{mg} / \mathrm{L}$ residual at $0.03 \mathrm{~m} / \mathrm{s} ; 490-550 \mathrm{~h}$ to reach $0.25 \mathrm{mg} / \mathrm{L}$ residual at $0.09 \mathrm{~m} / \mathrm{s}$ ) and imply that both surface reactions and mass transfer may limit reaction rate (Table 4-4). Increasing velocity was associated with an increase as observed in $\mathrm{k}_{\mathrm{w}}$ in both the present study and the literature, suggesting that mass transfer, which increases with velocity, impacts reaction rate (Table 4-4). 


\section{Chapter 5: Conclusions and Recommendations}

\section{Conclusions and Recommendations}

Overall, pipe material was the greatest contributor to chloramine decay. Specifically, cast-iron decay rates were $1000-30,000 \%$ higher than those for PVC. Based on these results, it may be worthwhile to examine alternative asset management strategies to reduce chloramine decay in future studies, such as lining cast iron pipe. Decay rates were 5.5-6.8 higher for CI pipe with surface deposits which suggests that their removal via routine maintenance activities such as swabbing may lead to improved chloramine residuals.

Bulk water decay rates were substantially lower than those for PSR trials, likely because the distribution system received chloraminated water, prior to sample collection. It is recommended that PSR trials be directly compared to traditional pipe loops in order to corroborate results and further assess the benefits associated with each technology. Future research in chloramine decay in distribution systems could also focus on the assessment of optimal maintenance to control biofilm as well as the potential impact of chloramine formation reagents on chloramine stability in distribution systems. 


\section{References}

Aisopou, Angeliki, Ivan Stoianov, Nigel Graham, and Bryan Karney. 2014. "Analytical and Experimental Investigation of Chlorine Decay in Water Supply Systems under Unsteady Hydraulic Conditions.” Journal of Hydroinformatics 16 (3): 690-709. https://doi.org/10.2166/hydro.2013.038.

American Public Health Association (APHA), American Water Works Association (AWWA), and Water Environment Foundation (WEF). 2012. Standard Methods for the Examination of Water and Wastewater. Edited by A.D. Eaton, L.S. Clesceri, E.W. Rice, and A.E. Greenberg. Standard Methods for the Examination of Water and Wastewater. Twentieth. Washington, USA.

Bakir, Bilal, Mehmet Tanyuksel, Fatma Saylam, Sultan Tanriverdi, R. Engin Araz, Ali Kasim Hacim, and Metin Hasde. 2003. "Investigation of Waterborne Parasites in Drinking Water Sources of Ankara, Turkey." Journal of Microbiology 41 (2): 148-51.

Bal Krishna, KC, Maneesha P Ginige, and Arumugam Sathasivan. 2018. "Is Nitrite from Nitrification the Only Cause of Microbiologically Induced Chloramine Decay?” Microbiology Australia. https://doi.org/10.1071/MA18044.

Baribeau, Hélène, Michèle Prévost, Raymond Desjardins, and Pierre Lafrance. 2001. "Changes in Chlorine and DOX Concentrations in Distribution Systems." Journal - American Water Works Association 93 (12): 102-14. https://doi.org/10.1002/j.1551-8833.2001.tb09359.x.

Clark, Robert M., and Roy C. Haught. 2005. "Characterizing Pipe Wall Demand: Implications for Water Quality Modeling." Journal of Water Resources Planning and Management ASCE 131 (3): 208-17. https://doi.org/10.1061/(ASCE)0733-9496(2005)131:3(208).

Cunliffe, D. A. 1991. "Bacterial Nitrification in Chloraminated Water Supplies.” Applied and Environmental Microbiology 57 (11): 3399-3402. https://doi.org/10.1128/aem.57.11.33993402.1991 .

DiGiano, F. A., and W. Zhang. 2005. "Pipe Section Reactor to Evaluate Chlorine-Wall Reaction.” Journal American Water Works Association 71 (1): 74-85. 
Douterelo, I., S. Husband, V. Loza, and J. Boxall. 2016. "Dynamics of Biofilm Regrowth in Drinking Water Distribution Systems." Applied and Environmental Microbiology 82 (14): 4155-68. https://doi.org/10.1128/AEM.00109-16.

Engineering Toolbox. 2004. "Hazen-Williams Coefficients.” 2004. https://www.engineeringtoolbox.com/hazen-williams-coefficients-d_798.html.

Fisher, Ian, George Kastl, and Arumugam Sathasivan. 2017. "New Model of Chlorine-Wall Reaction for Simulating Chlorine Concentration in Drinking Water Distribution Systems." Water Research 125: 427-37. https://doi.org/10.1016/j.watres.2017.08.066.

Hallam, N. B., J. R. West, C. F. Forster, J. C. Powell, and I. Spencer. 2002. "The Decay of Chlorine Associated with the Pipe Wall in Water Distribution Systems." Water Research 36 (14): 3479-88. https://doi.org/10.1016/S0043-1354(02)00056-8.

Health Canada. 2018. "Chloramines in Drinking Water: Document for Public Consultation."

Hoover, Sam R, Lenore Jasewicz, Janet B Pepinsky, and Nandor Porges. 1951. "Assimilation of Dairy Wastes by Activated Sludge.” Sewage and Industrial Wastes 23 (2): 167-73. https://www.jstor.org/stable/25031525.

Hua, Fang, J R West, R A Barker, and C F Forster. 1999. "Modelling of Chlorine Decay in Municipal Water Supplies." Water Research 33 (12): 2735-46. https://doi.org/https://doi.org/10.1016/S0043-1354(98)00519-3.

Huang, Huiping, Emma Sawade, David Cook, Christopher W.K. Chow, Mary Drikas, and Bo Jin. 2016. "High-Performance Size Exclusion Chromatography with a Multi-Wavelength Absorbance Detector Study on Dissolved Organic Matter Characterisation along a Water Distribution System." Journal of Environmental Sciences (China) 44: 235-43. https://doi.org/10.1016/j.jes.2015.12.011.

Jafvert, Chad T., and R Valentine. 1985. "A Unified Chlorine-Ammonia Speciation and Fate Model." Ph.D. Thesis. University of Iowa, Iowa City, Iowa.

Jafvert, Chad T., and Richard L. Valentine. 1992. "Reaction Scheme for the Chlorination of Ammoniacal Water." Environmental Science and Technology 26 (3): 577-86. 
https://doi.org/10.1021/es00027a022.

Jamwal, Priyanka, and M. S. Mohan Kumar. 2016. "Effect of Flow Velocity on Chlorine Decay in Water Distribution Network: A Pilot Loop Study.” Current Science 111 (8): 1349-54. https://doi.org/10.18520/cs/v111/i8/1349-1354.

Kiéné, L., W. Lu, and Y. Lévi. 1998. "Relative Importance of the Phenomena Responsible for Chlorine Decay in Drinking Water Distribution Systems." Water Science and Technology 38 (6): 219-27. https://doi.org/10.1016/S0273-1223(98)00583-6.

Kitis, Mehmet, Tanju Karanfil, Andrew Wigton, and James E. Kilduff. 2002. "Probing Reactivity of Dissolved Organic Matter for Disinfection By-Product Formation Using XAD-8 Resin Adsorption and Ultrafiltration Fractionation.” Water Research 36 (15): 383448. https://doi.org/10.1016/S0043-1354(02)00094-5.

Liu, Megan J, Stephen Craik, and David Z Zhu. 2015. "Determination of Cast Iron Pipe Wall Decay Coefficient for Combined Chlorine in a Municipal Water Distribution System.” Canadian Journal of Civil Engineering 42: 250-58. https://doi.org/10.1139/cjce-2014-0449.

Lyman, W.J., W.F. Reehl, and D.H. Rosenblatt. 1990. Handbook of Chemical Property Estimation Methods. Washington D.C.: American Chemical Society.

Menaia, J., S. T. Coelho, A. Lopes, E. Fonte, and J. Palma. 2003. "Dependency of Bulk Chlorine Decay Rates on Flow Velocity in Water Distribution Networks." Water Science and Technology: Water Supply 3 (1-2): 209-14. https://doi.org/10.2166/ws.2003.0105.

Mitch, William A, and David L. Sedlack. 2002. "Formation of N-Nitrosodimethylamine (NDMA) from Dimethylamine during Chlorination.” Environmental Science Technology 36: 588-95. https://doi.org/10.1021/es010684q.

Mobarak, A. A., H. A. Farag, and G. H. Sedahmed. 1997. "Mass Transfer in Smooth and Rough Annular Ducts under Developing Flow Conditions." Journal of Applied Electrochemistry 27 (2): 201-7. https://doi.org/10.1023/A:1018408125105.

Monteiro, Laura, David Figueiredo, Dídia Covas, and José Menaia. 2017. "Integrating Water Temperature in Chlorine Decay Modelling: A Case Study." Urban Water Journal 14 (10): 
1097-1101. https://doi.org/10.1080/1573062X.2017.1363249.

Moradi, Sina, Sanly Liu, Christopher W.K. Chow, John van Leeuwen, David Cook, Mary Drikas, and Rose Amal. 2017. "Chloramine Demand Estimation Using Surrogate Chemical and Microbiological Parameters." Journal of Environmental Sciences (China) 57: 1-7. https://doi.org/10.1016/j.jes.2017.01.010.

Mutoti, Ginasiyo Ignatius, John D. Dietz, Jorge Arevalo, and James S. Taylor. 2007. "Combined Chlorine Dissipation: Pipe Material, Water Quality, and Hydraulic Effects." Journal American Water Works Association 99 (10): 96-106. https://doi.org/10.1002/j.15518833.2007.tb08060.x.

Ontario Ministry of Environment. 2002. Ontario Regulation 170/03: Drinking Water Systems. Safe Drinking Water Act. https://www.ontario.ca/laws/regulation/030170.

Ozdemir, Osman N., and Tarik Buyruk. 2018. "Effect of Travel Time and Temperature on Chlorine Bulk Decay in Water Supply Pipes." Journal of Environmental Engineering (New York) 144 (3): 1-10. https://doi.org/10.1061/(ASCE)EE.1943-7870.0001321.

Ozdemir, Osman N., and Erhan Demir. 2007. "Experimental Study of Chlorine Bulk Decay in Water Supply Pipes.” Journal of Hydraulic Research 45 (6): 811-17. https://doi.org/10.1080/00221686.2007.9521818.

Piroiu, P., L. Kiene, and Y. Levi. 1997. "Study \& Modeling of Drinking Water Quality Evolution Using a Pipe Loop System." Proceedings of the Annual Meeting of the American Water Works Association, Atlanta, Georgia, USA. https://ci.nii.ac.jp/naid/80010399718/.

Potter, B B, and J C Wimsatt. 2005. "Measurement of Total Organic Carbon, Dissolved Organic Carbon and Specific UV Absorbance at $254 \mathrm{Nm}$ in Source Water and Drinking Water." DC: Environmental Protection Agency.

Powell, James C., Nicholas B. Hallam, John R. West, Christopher F. Forster, and John Simms. 2000. "Factors Which Control Bulk Chlorine Decay Rates." Water Research 34 (1): 117 26. https://doi.org/10.1016/S0043-1354(99)00097-4.

Rossman, Lewis A., Robert M. Clark, and Walter M. Grayman. 1994. "Modeling Chlorine 
Residuals in Drinking-Water Distribution Systems." Journal of Environmental Engineering 120 (4): 803-20. https://doi.org/10.1061/(asce)0733-9372(1994)120:4(803).

Rossman, Lewis A. 2000. "EPANET 2 Users Manual.” Cincinnati, Ohio.

Sarin, P., V. L. Snoeyink, D. A. Lytle, and W. M. Kriven. 2004. "Iron Corrosion Scales: Model for Scale Growth, Iron Release, and Colored Water Formation.” Journal of Environmental Engineering 130 (4): 364-73. https://doi.org/10.1061/(asce)0733-9372(2004)130:4(364).

Seidel, Andy, Matt Miller, and Paul Jorgensen. 2018. "Fine-Tune Chloramine Disinfectant Residual Levels in Distribution Networks." Opflow 44 (12): 22-25. https://doi.org/10.1002/opfl.1114.

Shang, Feng, James G. Uber, and Lewis A. Rossman. 2008. "Modeling Reaction and Transport of Multiple Species in Water Distribution Systems.” Environmental Science \& Technology 42 (3): 808-14. https://doi.org/10.1021/es072011z.

Subramanian, R Shankar. 2013. "Pipe Flow Calculations.” NY, U.S.

USEPA. 1998. “Stage 1 Disinfectants and Disinfection Byproducts Rule.” Federal Register 63 (241): 69390-476.

USEPA Health and Ecological Criteria Division, Office of Science and Technology, and Office of Water. 1994. "Drinking Water Criteria Document for Chloramines.” Cincinnati, Ohio.

Valentine, R.L., K. Ozekin, and P.J. Vikesland. 1998. Chloramine Decomposition in Distribution System and Model Waters. American Water Works Association Research Foundation and American Water Works Association. Denver, Colorado.

Vasconcelos, John J., Lewis A. Rossman, Walter M. Grayman, Paul F. Boulos, and Robert M. Clark. 1997. "Kinetics of Chlorine Decay." Journal - American Water Works Association 89 (7): 54-65. https://doi.org/10.1002/j.1551-8833.1997.tb08259.x.

Vikesland, Peter J., Kenan Ozekin, and Richard L. Valentine. 2001. "Monochloramine Decay in Model and Distribution System Waters.” Water Research 35 (7): 1766-76. https://doi.org/10.1016/S0043-1354(00)00406-1. 
Vikesland, Peter J., and Richard L. Valentine. 2000. "Reaction Pathways Involved in the Reduction of Monochloramine by Ferrous Iron.” Environmental Science \& Technology 34 (1): 83-90. https://doi.org/10.1021/es990511p.

Vikesland, Peter J, Richard L Valentine, and Kenan Ozekin. 1996. “Application of Product Studies in the Elucidation of Chloramine Reaction Pathways." In Water Disinfection and Natural Organic Matter, 649:105-114 SE - 7. ACS Symposium Series. American Chemical Society. https://doi.org/doi:10.1021/bk-1996-0649.ch007.

Wang, Zhikang, Onekyun Choi, and Youngwoo Seo. 2013. "Relative Contribution of Biomolecules in Bacterial Extracellular Polymeric Substances to Disinfection Byproduct Formation.” Environmental Science and Technology 47 (17): 9764-73. https://doi.org/10.1021/es402067g.

Westbrook, A., and F. A. DiGiano. 2009. "Rate of Chloramine Decay at Pipe Surfaces.” Journal (American Water Works Association) 101 (7): 59-70.

Woolschlager, J, B Rittmann, P Piriou, L Kiene, and B Schwartz. 2001. "Using a Comprehensive Model to Identify the Major Mechanisms of Chloramine Decay in Distribution Systems." Water Science and Technology: Water Supply 1 (4): 103-10. https://iwaponline.com/ws/article-pdf/1/4/103/108924/103.pdf.

World Health Organization. 2017. Guidelines for Drinking-Water Quality: Fourth Edition Incorporating the First Addendum. Geneva.

Xue, Zheng, Woo Hyoung Lee, Kimberly M. Coburn, and Youngwoo Seo. 2014. "Selective Reactivity of Monochloramine with Extracellular Matrix Components Affects the Disinfection of Biofilm and Detached Clusters." Environmental Science and Technology 48 (7): 3832-39. https://doi.org/10.1021/es405353h.

Zhang, C., C. Li, X. Zheng, J. Zhao, G. He, and T. Zhang. 2017. "Effect of Pipe Materials on Chlorine Decay, Trihalomethanes Formation, and Bacterial Communities in Pilot-Scale Water Distribution Systems." International Journal of Environmental Science and Technology 14 (1): 85-94. https://doi.org/10.1007/s13762-016-1104-2. 
Zhao, Yingying, Y Jeffrey Yang, Yu Shao, Jill Neal, and Tuqiao Zhang. 2018. "The Dependence of Chlorine Decay and DBP Formation Kinetics on Pipe Flow Properties in Drinking Water Distribution." Water Research 141: 32-45. https://doi.org/10.1016/j.watres.2018.04.048.The.

Zheng, Qi, Xiaoqiu Yang, Wenchao Deng, X. Chris Le, and Xing Fang Li. 2016.

"Characterization of Natural Organic Matter in Water for Optimizing Water Treatment and Minimizing Disinfection By-Product Formation.” Journal of Environmental Sciences (China) 42: 1-5. https://doi.org/10.1016/j.jes.2016.03.005. 


\section{$7 \quad$ Appendices}

\section{Appendix A: Standard Operating Procedures}

Table 7-1: Initial Water Quality Analysis

\section{Initial Water Quality Analysis}

1. Before sampling:

i. Rinse 10 L blue High-Density Polyethylene (HDPE) carboys $2 \mathrm{x}$ with DI water and $1 \mathrm{x}$ with Elix water.

ii. Label HDPE carboys.

iii. $\quad$ Rinse sample tubing $2 \mathrm{x}$ with DI water and 1x with Elix water for $30 \mathrm{~s}$.

iv. Bring gloves, $\mathrm{pH}$ probe, temperature probe, $\mathrm{DO}$ probe, conductivity meter to site.

2. Collect water from the Newmarket distribution system: $3 \times 10$ L carboys of water originating from groundwater and $3 \times 10$ L carboys of water originating from surface water.

3. Allow water to run for approximately 3 minutes before sample collection.

4. When collecting the sample, place tubing in the bottom of the carboy to avoid aerating the sample.

5. At each site, measure and record the water $\mathrm{pH}$, temperature, $\mathrm{DO}$, and conductivity.

6. After returning to the lab, measure temperature, $\mathrm{DO}, \mathrm{pH}$, free chlorine, total chlorine, monochloramine, conductivity, UV254 absorbance, and DOC.

7. Calculate SUVA.

8. Prepare $400 \mathrm{~mL}$ of each groundwater/ surface water mixture using volumetric flasks.

9. Transfer $\sim 200 \mathrm{~mL}$ of each solution to a beaker for water quality analysis in duplicates.

10. Measure the $\mathrm{pH}$ of each groundwater/ surface water mixture with the $\mathrm{pH}$ meter.

11. Measure the DO concentration of each mixture with the DO meter.

12. Determine the total chlorine, free chlorine, and chloramine concentrations of each sample

13. using the HACH DR 2700 spectrophotometer and appropriate powder pillows.

14. Filter and transfer 3 aliquots of each sample to $40 \mathrm{~mL}$ amber vials for DOC analysis.

15. If DOC analysis is not completed immediately, acidify and store samples at $4{ }^{\circ} \mathrm{C}$ and analyze within 14 days.

16. Conduct DOC analysis. 
Table 7-2: Preparation of Stock Solutions and Monochloramine

\section{Preparation of Stock Solutions and Monochloramine}

1. Prepare $\mathrm{pH} 8$ buffer consisting of a $100 \mathrm{~mL}$ solution of Milli-Q water with $0.8506 \mathrm{~g}$ sodium borate and $5.6309 \mathrm{~g}$ boric acid.

2. Prepare $\sim 2000 \mathrm{mg} / \mathrm{L}$ chlorine stock solution from the $10-15 \% \mathrm{NaOCl}$ stock solution from Sigma-Aldrich.

a. Add about $300 \mathrm{~mL}$ of Milli-Q water to a $500 \mathrm{~mL}$ volumetric flask.

b. Add $50 \mathrm{~mL}$ of $10-15 \% \mathrm{NaOCl}$ stock to the $500 \mathrm{~mL}$ volumetric flask. Mix the contents of the flask, and then raise the volume of the flask to $500 \mathrm{~mL}$ with Milli-Q water.

c. Next, aliquot $5 \mathrm{~mL}$ of the diluted stock to a new $100 \mathrm{~mL}$ volumetric flask and again raise the volume of the flask to $100 \mathrm{~mL}$ with Milli-Q water.

d. Next, aliquot $2 \mathrm{~mL}$ of the new dilution to a new $100 \mathrm{~mL}$ volumetric flask and raise the volume to $100 \mathrm{~mL}$ with Milli-Q.

e. Aliquot $25 \mathrm{~mL}$ of this stock to the spectrophotometer sample vial. Add a free chlorine powder pillow, shake the sample for 5 seconds, then measure and record the concentration of the sample after an additional 20 seconds.

f. Calculate the concentration of the stock solution based on the dilution and measured free chlorine concentration.

3. Prepare $3.30 \mathrm{~g} / \mathrm{L}$ stock solution of ammonium chloride from $\mathrm{NH} 4 \mathrm{Cl}$ and Milli-Q.

a. Add $1.65 \mathrm{~g} \mathrm{NH} 4 \mathrm{Cl}$ to $500 \mathrm{~mL}$ Milli-Q and transfer to an amber glass bottle.

b. Refrigerate the stock solution for at least 2 hours prior to use.

4. Prepare a stock solution of monochloramine.

a. Add $50 \mathrm{~mL} \mathrm{NH} 4 \mathrm{Cl}$ and a stir bar to a $140 \mathrm{~mL}$ beaker in an ice bath.

b. Stir the solution such that a vortex is maintained for the duration of the experiment.

c. Pipette $5 \mathrm{~mL}$ of $\mathrm{pH} 8$ buffer to the solution.

d. Pipette $67.5 \mathrm{~mL}$ of $2000 \mathrm{mg} / \mathrm{L}$ chlorine slowly to the solution.

e. Allow the reaction to proceed for 1.5 hours.

f. Dilute monochloramine solution $1000 \mathrm{x}$ by adding $0.1 \mathrm{~mL}$ of the solution to a $100 \mathrm{~mL}$ volumetric flask and raising the volume to $100 \mathrm{~mL}$ with Milli-Q.

g. Measure the concentration of the diluted monochloramine with the HACH DR 2700 spectrophotometer set to 66 Monochloramine LF and a Monochlor F powder pillow.

h. Aliquot $25 \mathrm{~mL}$ of the diluted monochloramine to the spectrophotometer sample vial, add the Monochlor F powder pillow, and allow to react for 5 minutes.

i. Measure the concentration of monochloramine, aiming for $1 \mathrm{mg} / \mathrm{L}$ of the diluted sample or $1000 \mathrm{mg} / \mathrm{L}$ of the freshly prepared stock. 
Table 7-3: Chloramination and Chlorine Analysis

\section{Chloramination and Chlorine Analysis}

1. Prepare a stock solution of monochloramine following the method from Zhao, 2016.

2. Measure the initial monochloramine concentration of the water sample in the Pipe Section Reactor. Spike the water sample with monochloramine to a concentration of $2.5 \mathrm{mg} / \mathrm{L} \pm 0.3$ $\mathrm{mg} / \mathrm{L}$.

3. Measure total chlorine, free chlorine, chloramine, and free ammonia concentrations of duplicate samples collected from the Pipe Section Reactor at 0 h, 6 h, 24 h, 30 h, 48 h, 54 h, and $72 \mathrm{~h}$ for PVC PSRs and amber glass bottles and every hour from 0-6 h for CI PSRs and amber glass bottles.

Table 7-4: Preparation of Chloramine Demand Free Bottles

\section{Preparation of Chloramine Demand Free Bottles}

1. Add $1.5 \mathrm{~mL}$ bleach, stored in the cabinet next to sink in dishwashing room, per $250 \mathrm{~mL}$ of bottle volume.

2. Fill bottles headspace-free with DI water.

3. After $24 \mathrm{~h}$, rinse bottles $2 \mathrm{x}$ with DI water and $1 \mathrm{x}$ with Elix water.

4. Label bottles and store them at room temperature.

Table 7-5: Reducing Chloramine Demand in the Pipe Section Reactors Prior to Experiments

\section{Reducing Chloramine Demand in the Pipe Section Reactors Prior to Experiments}

1. Clean the acrylic outer cylinder and inner cylinder by scrubbing with a solution of $300 \mu \mathrm{L}$ dish soap and $600 \mu \mathrm{L}$ of bleach per $100 \mathrm{~mL}$ of DI water.

2. Rinse the outer and inner cylinder $2 \mathrm{x}$ with DI and $1 \mathrm{x}$ with Elix water.

3. Reassemble the reactor.

4. Add $1.5 \mathrm{~mL}$ bleach, stored in the cabinet next to sink in dishwashing room, per $250 \mathrm{~mL}$ of reactor volume.

5. Fill the Pipe Section Reactor headspace-free with DI water.

6. After $24 \mathrm{~h}$, rinse the Pipe Section Reactor 2x with DI water and 1x with Elix water. 
Table 7-6: Setting up Pipe Section Reactor Experiments

\section{Setting up Pipe Section Reactor Experiments}

1. Remove carboys from the walk-in fridge. For $72 \mathrm{~h}$ experiments with 3 PSRs, remove $5 \mathrm{x}$ 10 L carboys.

2. Make sure that there is nothing blocking the chiller condenser. Turn on Chiller. Check 50/50 propylene glycol/ water levels to ensure that the copper coils are covered. If necessary, add more 50/50 propylene glycol/ water to cover the coils. The chiller setpoint should be $40^{\circ} \mathrm{F}$.

3. Begin preparing the monochloramine solution.

4. Turn on the PSR Raspberry Pis and open the motor controller code (MotorTest.py) on each Raspberry Pi.

5. Measure the initial total chlorine concentration in all carboys.

6. Fill 2 chlorine demand-free $1 \mathrm{~L}$ amber glass bottles with water from one of the carboys.

7. Measure the concentration of the fresh monochloramine stock solution.

8. Calculate the required volume of monochloramine to be added to each PSR, to the amber glass bottles, and to the extra carboys to reach a concentration of $2.5 \mathrm{mg} / \mathrm{L}$.

9. Fill each PSR with water from the carboys.

10. Dose PSRs and amber glass bottles with monochloramine.

11. Dose the extra carboys with monochloramine.

12. Store the extra carboys and the amber glass bottles in the mini-fridge at $12^{\circ} \mathrm{C}$.

Table 7-7: Sampling from the Pipe Section Reactors

\section{Sampling from the Pipe Section Reactors}

1. Unscrew the PSR pressure vent and fill 2 clean, labelled beakers with approximately 125 $\mathrm{mL}$ of water from the PSR.

2. Refill the PSR with chloraminated water from the extra carboys and seal the PSR. 
Table 7-8: Tracer Dye Velocity Calibration Method

\section{Tracer Dye Velocity Calibration Method}

1. Mark a 14" long section of Pipe Section Reactor, centred lengthwise along the Pipe Section Reactor.

2. Add foam sphere to the Pipe Section Reactor.

3. Inject $2 \mathrm{~mL}$ of $125 \mathrm{mg} / \mathrm{L}$ Rhodamine B tracer dye into the septa of the Pipe Section Reactor.

4. Set motor power to $5 \%$.

5. Allow the reactor to recirculate water for 1 minute or until the water flow appears to reach steady state. Monitor circulation of the foam sphere to ensure the flow is consistent.

6. Measure the pressure differential produced by the water flow on the Raspberry Pi.

7. Measure the amount of time it takes for the tracer dye to travel along the 14" section of the Pipe Section Reactor by recording a video of the dye's motion.

8. Drain pipe section reactor, refill with tap water, and repeat steps 5-7 at least two times.

9. Repeat steps 3-7 until 5\%, 15\%, 25\%, 35\%, 45\%, and 55\% power have been tested.

Table 7-9: Inkbird Temperature Controller Calibration Method

\section{Inkbird Temperature Controller Calibration Method}

1. Read the Inkbird temperature controller manual.

2. Plugin the Inkbird temperature controller.

3. Place the Inkbird temperature probe and the thermometer in the ice bath.

4. Hold the set button for $3 \mathrm{~s}$.

5. When tS flashes on the screen, change the temperature setpoint to the desired temperature and press set.

6. Set $\mathrm{Hd}$ and $\mathrm{Cd}$ to the desired heating and cooling differential values.

7. Press set until CA appears on the screen to calibrate the temperature controller by comparing the displayed temperature on the Inkbird sensor to the temperature.

8. Once the Inkbird temperature is calibrated, hold the set button for 3 seconds, and the Inkbird Temperature controller is ready for use. 
Table 7-10: Pressure Transmitter Calibration Method

\section{Pressure Transmitter Calibration Method}

The two pressure transducers were calibrated using a 40 L Nalgene tank by measuring the output signal produced by applying varying increments of water pressure to each transducer. Applied pressures were $0.0,3.0,6.0,9.0,12.0,15.0$, and 18.0 inches of water; this is equivalent to 0.00 , $0.11,0.22,0.32,0.43,0.54$, and 0.65 psi. The pressure transducers are designed to measure pressures from 0-5 psi by outputting a current from 4-20 mA. This means that at atmospheric pressure, equivalent to an applied pressure of 0 psi, the transducers should emit a $4 \mathrm{~mA}$ signal. Correspondingly, at an applied pressure of 5 psi, the transducers should produce a $20 \mathrm{~mA}$ signal.

1. Measure the height of the $40 \mathrm{~L}$ Nalgene tank and label the side of the tank in 1" increments. Begin height measurements from the middle of the height of the effluent tap.

2. Screw the pressure transducer onto the ball valve of the calibration tank until fingertight.

3. Record the initial pressure reading in $\mathrm{mA}$ by running file mAread.py Raspberry Pi. This value will correspond to an applied pressure of 0 in. $\mathrm{H}_{2} \mathrm{O}$.

4. Begin filling the tank to the 3.0 in. mark. Ensure that there are no leaks in the seal between the pressure transducer and the ball valve. Make sure that the ball valve is open.

5. Once the water height has reached the 3.0 in. mark, wait for the reading on Raspberry Pi to stabilize and record the output signal of the pressure transducer in $\mathrm{mA}$.

6. Repeat step 5 for water heights of $6.0 \mathrm{in.,} 9.0 \mathrm{in} ., 12.0 \mathrm{in} ., 15.0 \mathrm{in}$., and $18.0 \mathrm{in.}$

7. Once all of the pressure signals have been recorded, close the ball valve and remove the pressure transducer.

8. Open the ball valve and empty the tank. 


\section{Table 7-11: Chiller Operation}

\section{Chiller Operation}

1. Ensure that the chiller is filled with sufficient 50/50 propylene glycol/ water to cover the copper cooling coils in the reservoir.

2. Turn on the chiller. The setpoint should be $40{ }^{\circ} \mathrm{F}$

3. Unplug the pump power adaptor until the Pipe Section Reactors have been filled with water samples.

4. Once the PSRs have been filled, plug in the pump power adaptors. 


\section{Appendix B: Estimating Water Velocity in PVC and Cast- Iron Pipe Segments}

To estimate the water velocity in Pipe Section Reactors constructed with cast iron or PVC, it is suggested to use Hazen-Williams roughness coefficients (Table 7-12) to create a proportionality constant relating the velocity in the distribution system pipe to that measured for the acrylic pipe.

Table 7-12: Hazen-Williams coefficients for various pipe materials

\begin{tabular}{cc}
\hline Material & Hazen-Williams Coefficient (Engineering Toolbox, 2004) \\
\hline Cast-Iron new unlined & 130 \\
Cast-Iron aged 40 years & 64 \\
Plastic (Acrylic) & 140 \\
PVC & 150
\end{tabular}

The Hazen-Williams equation can be used to determine pressure losses due to friction in various pipe materials and is represented as follows:

$$
\mathrm{V}=\mathrm{kCR} \mathrm{R}^{0.63} \mathrm{~S}^{0.54}
$$

Equation 5

Where $\mathrm{v}$ is the water velocity, $\mathrm{k}$ is an empirical constant $(0.849), \mathrm{R}$ is the hydraulic radius of the pipe, and $\mathrm{S}$ is the slope of the pipe segment.

In order to determine the velocity in a pipe segment $\left(\mathrm{V}_{2}\right)$ based on the velocity measured in an acrylic pipe segment $\left(\mathrm{V}_{1}\right)$, it is possible to rearrange Equations 6 and 7 to Equation 8:

$$
\begin{array}{cc}
\mathrm{V}_{1}=\mathrm{kC}_{1} \mathrm{R}_{1}{ }^{0.63} \mathrm{~S}_{1}{ }^{0.54} & \text { Equation } 6 \\
\mathrm{~V}_{2}=\mathrm{kC}_{2} \mathrm{R}_{2}{ }^{0.63} \mathrm{~S}_{2}{ }^{0.54} & \text { Equation } 7 \\
\frac{V_{1}}{\mathrm{C}_{1} \mathrm{R}_{1}^{0.63} \mathrm{~S}_{1}^{0.54}}=\frac{V_{2}}{\mathrm{C}_{2} \mathrm{R}_{2}^{0.63} \mathrm{~S}_{2}^{0.54}}=\mathrm{k} & \text { Equation } 8
\end{array}
$$

Next, if the hydraulic radius and slope are the same for the two pipe segments, Equation 8 can be simplified:

$$
\frac{V_{1}}{C_{1}}=\frac{V_{2}}{C_{2}}
$$

Finally, rearranging to solve for $\mathrm{V}_{2}$ :

$$
V_{2}=\frac{V_{1} C_{2}}{C_{1}}
$$

Equation 10 
Based on the velocity calibration curve prepared for acrylic pipe, the velocities in other pipe materials at a given motor power may be estimated (Figure 7-1):

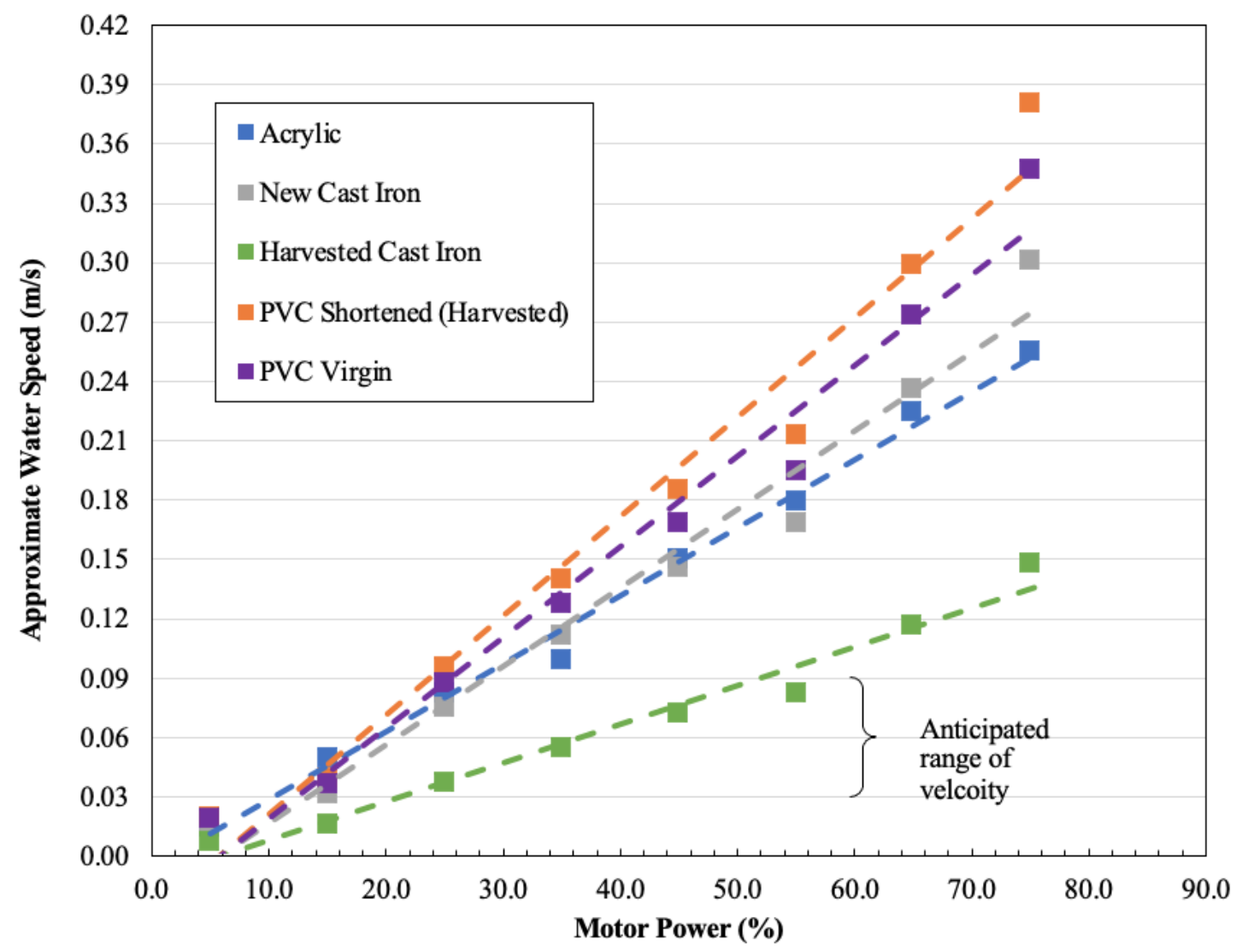

Figure 7-1: Estimated Flow Velocity vs. Motor Power for Ductile Iron, PVC, New Cast-Iron, and Old Cast-Iron Based on Hazen-Williams Roughness Coefficients.

To estimate the water velocity in a Pipe Section Reactor constructed a shortened segment of harvested pipe $(0.51 \mathrm{~m}$ compared to typical $0.61 \mathrm{~m})$, it is suggested to determine the relationship between water velocity and pipe length at a constant motor power using Equations 11 through 15 (Subramanian, 2013).

Firstly, 
Where Power is the power needed to produce a given flow rate of water, which will be considered constant at a given percent motor power $(\mathrm{W}), \Delta \mathrm{P}$ is the pressure drop due to friction losses in the pipe $(\mathrm{Pa})$, and $\mathrm{Q}$ is the volumetric flow rate of water in the pipe $\left(\mathrm{m}^{3} / \mathrm{s}\right)$

$$
\Delta \mathrm{P}=2 \mathrm{f} \frac{\mathrm{L}}{\mathrm{D}} \rho \mathrm{V}^{2}
$$

Where $\Delta \mathrm{P}$ is the pressure drop due to friction losses in the pipe $(\mathrm{Pa}), \mathrm{f}$ is the Fanning friction factor, $\mathrm{L}$ is the pipe length (m), D is the diameter of the pipe $(\mathrm{m}), \rho$ is the density of the flowing fluid $\left(\mathrm{kg} / \mathrm{m}^{3}\right)$, and $\mathrm{V}$ is the water velocity along the pipe wall $(\mathrm{m} / \mathrm{s})$

$$
\mathrm{f}=\frac{16}{\operatorname{Re}}
$$

Equation 13

For laminar flow where $\mathrm{f}$ is the Fanning friction factor (unitless), and Re is the Reynolds number (unitless)

$$
\mathrm{Q}=\frac{\pi}{4} \mathrm{D}^{2} \mathrm{~V}
$$

Equation 14

Where $\mathrm{Q}$ is the volumetric flow rate of water in the pipe $\left(\mathrm{m}^{3} / \mathrm{s}\right), \mathrm{D}$ is the diameter of the pipe $(\mathrm{m})$, and $\mathrm{V}$ is the water velocity along the pipe wall $(\mathrm{m} / \mathrm{s})$

$$
\operatorname{Re}=\frac{\operatorname{DV} \rho}{\mu}
$$

Where D is the diameter of the pipe $(\mathrm{m}), \mathrm{V}$ is the water velocity along the pipe wall $(\mathrm{m} / \mathrm{s}), \rho$ is the density of the flowing fluid $\left(\mathrm{kg} / \mathrm{m}^{3}\right)$, and $\mu$ is the dynamic viscosity of the flowing fluid $\left(\mathrm{Pa}^{*} \mathrm{~s}\right)$

Substituting Equation 12 and Equation 14 into Equation 11:

$$
\begin{gathered}
\text { Power }=2 f \frac{L}{D} \rho V^{2} \frac{\pi}{4} D^{2} V= \\
f \frac{L}{D} \rho V^{3} \frac{\pi}{2} D^{2}
\end{gathered}
$$

Substituting Equation 13 into Equation 16:

$$
\begin{gathered}
\text { Power }=\frac{16}{\operatorname{Re}} \frac{\mathrm{L}}{\mathrm{D}} \rho \mathrm{V}^{3} \frac{3}{2} \mathrm{D}^{2}= \\
\frac{8}{\operatorname{Re}} \mathrm{L} \rho \mathrm{V}^{3} \pi \mathrm{D}
\end{gathered}
$$


Substituting Equation 15 into Equation 17:

$$
\begin{gathered}
\text { Power }=\frac{8}{\frac{8 V \rho}{\mu}} L_{\rho} \mathrm{V}^{3} \pi \mathrm{D}= \\
8 \mu \mathrm{LV}^{2} \pi
\end{gathered}
$$

Equation 18

Using Equation 18, in order to assess the relationship between pipe length and water velocity along the pipe wall, let Power 1 and Power2 2 be the powers associated with a given percent motor power (e.g., $25 \%$ motor power). $L_{1}$ is the measured length of pipe segment $1(\mathrm{~m}), \mathrm{V}_{1}$ is the measured water velocity in pipe segment $1(\mathrm{~m} / \mathrm{s}), \mathrm{L}_{2}$ is the measured length of pipe segment $2(\mathrm{~m})$, and $\mathrm{V}_{2}$ is the unknown water velocity in pipe segment $2(\mathrm{~m} / \mathrm{s})$.

$$
\begin{array}{ll}
\text { Power }_{1}=8 \mu \mathrm{L}_{1} \mathrm{~V}_{1}{ }^{2} \pi & \text { Equation } 19 \\
\text { Power }_{2}=8 \mu \mathrm{L}_{2} \mathrm{~V}_{2}{ }^{2} \pi & \text { Equation } 20
\end{array}
$$

For a given motor power percentage, the Power is constant, so Equation $19=$ Equation 20, and the two equations can be rearranged and simplified in order to solve for $\mathrm{V}_{2}$ :

$$
\begin{aligned}
& \text { Power }_{1}=\text { Power }_{2}=\mathrm{L}_{1} \mathrm{~V}_{1}{ }^{2}= \\
& \mathrm{L}_{2} \mathrm{~V}_{2}{ }^{2}
\end{aligned}
$$

Equation 21

Further rearranging Equation 21 to solve for $\mathrm{V}_{2}$ :

$$
\mathrm{V}_{2}=\sqrt{\frac{L_{1} V_{1}^{2}}{L_{2}}}
$$

This relationship can be used to estimate the water velocity in the pipe wall for the shortened PVC pipe segment $(0.51 \mathrm{~m})$, based on the estimated water velocity for a $0.61 \mathrm{~m}$ PVC pipe segment. 